International Center for Public Policy Working Paper 14-26 June 2014
Tax Evasion, the Provision of Public Infrastructure, and Growth: A General Equilibrium Approach to Two Very Different Countries, Egypt and Mauritius

Andrew Feltenstein Jeffrey Condon Biplab Kumar Datta 

International Center for Public Policy

Working Paper 14-26

\section{Tax Evasion, the Provision of Public Infrastructure, and Growth: A General Equilibrium Approach to Two Very Different Countries, Egypt and Mauritius}

\section{Andrew Feltenstein Jeffrey Condon Biplab Kumar Datta}

\section{June 2014}

International Center for Public Policy

Andrew Young School of Policy Studies

Georgia State University

Atlanta, Georgia 30303

United States of America

Phone: (404) 651-1144

Fax: (404) 651-4449

Email: hseraphin@gsu.edu

Internet: http://aysps.gsu.edu/isp/index.html

Copyright 2006, the Andrew Young School of Policy Studies, Georgia State University. No part of the material protected by this copyright notice may be reproduced or utilized in any form or by any means without prior written permission from the copyright owner. 


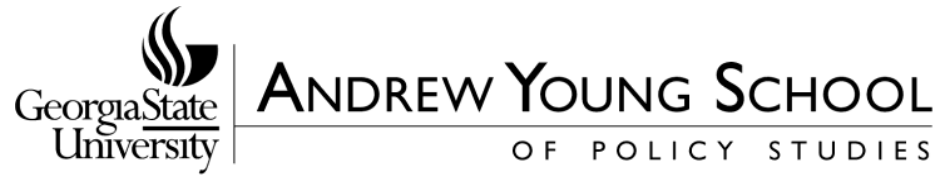

\section{International Center for Public Policy Andrew Young School of Policy Studies}

The Andrew Young School of Policy Studies was established at Georgia State University with the objective of promoting excellence in the design, implementation, and evaluation of public policy. In addition to two academic departments (economics and public administration), the Andrew Young School houses seven leading research centers and policy programs, including the International Center for Public Policy.

The mission of the International Center for Public Policy is to provide academic and professional training, applied research, and technical assistance in support of sound public policy and sustainable economic growth in developing and transitional economies.

The International Center for Public Policy at the Andrew Young School of Policy Studies is recognized worldwide for its efforts in support of economic and public policy reforms through technical assistance and training around the world. This reputation has been built serving a diverse client base, including the World Bank, the U.S. Agency for International Development (USAID), the United Nations Development Programme (UNDP), finance ministries, government organizations, legislative bodies and private sector institutions.

The success of the International Center for Public Policy reflects the breadth and depth of the in-house technical expertise that the International Center for Public Policy can draw upon. The Andrew Young School's faculty are leading experts in economics and public policy and have authored books, published in major academic and technical journals, and have extensive experience in designing and implementing technical assistance and training programs. Andrew Young School faculty have been active in policy reform in over 40 countries around the world. Our technical assistance strategy is not to merely provide technical prescriptions for policy reform, but to engage in a collaborative effort with the host government and donor agency to identify and analyze the issues at hand, arrive at policy solutions and implement reforms.

The International Center for Public Policy specializes in four broad policy areas:

- Fiscal policy, including tax reforms, public expenditure reviews, tax administration reform

- Fiscal decentralization, including fiscal decentralization reforms, design of intergovernmental transfer systems, urban government finance

- Budgeting and fiscal management, including local government budgeting, performancebased budgeting, capital budgeting, multi-year budgeting

- Economic analysis and revenue forecasting, including micro-simulation, time series forecasting,

For more information about our technical assistance activities and training programs, please visit our website at http://aysps.gsu.edu/isp/index.html or contact us by email at hseraphin@gsu.edu. 


\title{
Tax Evasion, the Provision of Public Infrastructure, and Growth: A General Equilibrium Approach to Two Very Different Countries, Egypt and Mauritius. ${ }^{1}$
}

\author{
Andrew Feltenstein, Jeffrey Condon, and Biplab Kumar Datta \\ Georgia State University
}

\begin{abstract}
We construct a dynamic multi-period general equilibrium model and use it to analyze prospects for growth in two very different countries, Egypt and Mauritius. The use of a single model has the advantage that when comparing alternative policies across countries, it is not necessary to worry if different conclusions are based solely upon model differences, as would be the case with multiple models.

In the case of Egypt we look at the effects of the revolution of 2011 on growth, in particular, at the impact of a dramatic decline in tourism. In addressing the issue of how to increase growth we focus upon a particular problem in Egypt, namely the low rate of tax compliance. Accordingly, we look at fiscal policies designed to reduce tax evasion, and find that these policies are also successful in modestly increasing GDP growth.

Mauritius has not suffered from any immediate shock, as has Egypt. However shortages in public infrastructure have been identified as bottlenecks in GDP growth, which has slowed in recent years. We therefore estimate elasticities of private production with respect to stocks of public infrastructure, and use these elasticities to implement our general equilibrium model. We find that modest increases in spending upon public infrastructure, compensated for by corresponding decreases in current spending, can lead to increases in real GDP growth. Beyond certain levels, however, more infrastructure spending will actually lead to a decline in real GDP growth.
\end{abstract}

\footnotetext{
${ }^{1}$ We would like to thank Nour Abdul-Razzak of the University of Chicago, who did important earlywork on Egyptian tax evasion that greatly helped us, Professor Hanan Nazier of Cairo University, who provided us with the social accounting matrix that formed the basis for the Egyptian general equilibrium model, and the late Professor Manal Metwaly of Cairo University, who was responsible for starting this project and whom we greatly miss.
} 


\section{Introduction}

The analysis of real economic growth in developing countries often focuses upon the important role played by the public sector, as well as the response of the private sector to public policies. More specifically, certain economies may appear to face impediments to growth that are either the result of public policies, or that might be alleviated by changed public policies. In this paper we will look at two such countries, Egypt and Mauritius, each of which wishes to increase its real growth rate yet faces obstacles that are quite different for each country.

Egypt has suffered a decline in real growth rates since the events of 2011. The most immediate causes of this decline have been a drop in tourism and a decline in foreign direct investment (FDI). At the same time, the country has long term problems with tax evasion. We will use an intertemporal general equilibrium model to see whether changes in the fiscal regime, designed to reduce tax evasion, can also enhance real growth. Mauritius, on the other hand, faces bottlenecks caused by shortages of public infrastructure. Is it possible to use the same structural model to analyze Mauritius' growth problems that we use for Egypt? Doing so would allow us to avoid the question of whether different outcomes for different countries were simply a result of using alternative models, rather than inherent differences between the countries.

We will now briefly describe the current economic situations of Egypt and Mauritius. We will then outline the general equilibrium model we use to analyze growth enhancing fiscal policies for the two countries. We then will use numerical implementations of the model, based upon data for the countries, to draw certain policy conclusions. 


\section{Country Backgrounds}

\section{a. Egypt}

Over the past twenty years, Egypt has transformed its economy. Beginning in 1991 with the Economic Reform and Structural Adjustment Program, Egypt restored macroeconomic equilibrium by increasing the role of the private sector, relaxing price controls, reducing trade restrictions, and reducing inflation and budget deficits. Modest tax reform took place in 2001 with the general sales tax extended to the wholesale and retail sectors. Major reforms were enacted in 2005. The top personal income tax rate was decreased from $32 \%$ to $20 \%$. Taxes on corporate profit were cut from $40 \%$ to $20 \%$ on profits under 10 million EGP and $25 \%$ on profits above. Property tax rates were cut from $46 \%$ to $10 \%$. Sales taxes were standardized and cut from $46 \%$ to $30 \%$ for luxury goods, $3 \%$ to $0 \%$ for essential goods, and a uniform rate of $10 \%$ for all non-luxury, nonessential goods.

Following the major fiscal and monetary reforms in 2005, Egypt's economy tracked in a generally positive direction. Growth rates reached as high as $7.2 \%$ before the financial crisis, and afterwards reached a low of $4.7 \%$. Unemployment fell from a 2005 rate of $11.5 \%$ to $9 \%$ in 2010. Debt to GDP fell to $70 \%$ in 2008 from 103\%. Inflation, however, rose from $4.7 \%$ to 20.2\%. In January of 2011 The direct effects of the revolution on the economy were large. During the revolution, crime rates rose causing tourism to fall dramatically. Tourism in 2010 accounted for $13 \%$ of GDP, $11 \%$ of total employment, $\$ 14$ billion in export revenue, and $22 \%$ of total exports (WTTC, 2010). According to the Central Agency for Public Mobilization and Statistics (CAPMAS), in 2011 tourism fell by one third. Outside sources have put the figure as 
high as $70 \%^{2}$. After the revolution, unemployment increased from $9 \%$ to $12.1 \%$, real GDP growth fell from $5.1 \%$ to $1.8 \%$.

The new Egyptian government has inherited an economy with significant problems. GDP growth fell to an annualized rate of $1 \%$ in the first quarter of 2014. GDP forecasts for 2014 are between $2 \%$ and $2.5 \%$. The deficit is currently at $13 \%$ of GDP with a debt to GDP ratio of nearly 90\%. Aid from Saudi Arabia and others has kept foreign reserves above the 3 month minimum, but inflation has recently increased over the last few months from the $7.6 \%$ annual rate to a monthly rate revealing annual inflation of more than $13 \%$.

TABLE 1 - Egyptian Economy Before and After 2005 Tax Reforms and 2011 Revolution

\begin{tabular}{cccccccc}
\hline Year & $\begin{array}{c}\text { Nominal GDP } \\
\text { (Billion US\$) }\end{array}$ & $\begin{array}{c}\text { Real GDP } \\
\text { (Billion EGP) }\end{array}$ & $\begin{array}{c}\text { Real GDP } \\
\text { Growth Rate }\end{array}$ & $\begin{array}{c}\text { Price Index } \\
(1999=100)\end{array}$ & $\begin{array}{c}\text { Inflation } \\
\text { Rate }\end{array}$ & $\begin{array}{c}\text { Unemployment } \\
\text { Rate }\end{array}$ & $\begin{array}{c}\text { Gov't Debt } \\
\text { (\% of GDP) }\end{array}$ \\
\hline 2000 & 100 & 355 & 5.4 & 101.1 & 1.1 & 9.0 & n/a \\
2001 & 97 & 367 & 3.5 & 103.4 & 2.3 & 8.8 & n/a \\
2002 & 86 & 379 & 3.2 & 106.2 & 2.7 & 10.1 & 90.4 \\
2003 & 81 & 391 & 3.2 & 110.5 & 4.1 & 11.3 & 102.3 \\
2004 & 79 & 407 & 4.1 & 123.4 & 11.7 & 10.5 & 101.5 \\
2005 & 90 & 425 & 4.5 & 129.2 & 4.7 & 11.5 & 103.3 \\
2006 & 107 & 454 & 6.8 & 138.5 & 7.2 & 10.9 & 90.3 \\
2007 & 130 & 487 & 7.1 & 150.4 & 8.6 & 9.2 & 80.2 \\
2008 & 162 & 521 & 7.2 & 180.7 & 20.2 & 8.8 & 70.2 \\
2009 & 189 & 546 & 4.7 & 198.7 & 10.0 & 9.5 & 73.0 \\
2010 & 219 & 574 & 5.1 & 220.0 & 10.7 & 9.0 & 73.2 \\
2011 & 236 & 584 & 1.8 & 245.9 & 11.8 & 12.1 & 76.6 \\
2012 & 262 & 597 & 2.2 & 272.5 & 10.8 & 12.3 & 80.6 \\
2013 & 271 & 609 & 2.1 & 289.5 & 6.2 & 13.0 & 89.5 \\
\hline
\end{tabular}

Source: International Monetary Fund, World Economic Outlook Database, April 2014

$* *$ At an exchange rate of $\$ 1=£ 0.155$, Egyptian Nominal GDP is approximately $£ 1,753$ in 2013.

\footnotetext{
${ }^{2}$ It is difficult to use CAPMAS data for tourism because Tunisian, Libyan, and other refugees cannot be separated from tourists.
} 


\section{Tax Evasion}

High levels of tax evasion represent serious challenges for many developing nations as they seek to grow and to expand their public services. With trade liberalization being a part of many reforms in developing nations, there is a need to increase domestic revenues to replace the revenues lost from decreased tariffs (Toye 2000). Furthermore, there is the threat of a large informal economy, with citizens migrating to the informal economy if taxes are too high or too cumbersome to pay (Turnovsky and Basher 2009). There is a need to develop policies that can creatively increase tax compliance while also promoting economic growth.

Egypt is an interesting case as it has transformed itself in the past thirty years from being an economy dominated by the public sector to a private sector and market-oriented economy (Dobronogov et al. 2005). At the same time, Egypt has implemented a series of tax reforms. Although many other Arab countries have undergone tax reforms and structural adjustment programs, Egypt is the largest and most diverse non-oil based Arab economy to undergo such extensive reforms. Egypt has seen moderate growth since the structural adjustment programs were implemented. However following the global financial crisis of 1997 and a domestic financial scandal of 1998, Egypt's economic growth initially slowed and failed to maintain a higher growth rate. Prior to the revolution, negative global shocks continued and Egypt's fiscal situation deteriorated with budget deficits steadily increasing. According to the IMF, fiscal vulnerabilities remain as Egypt's main macroeconomic risk (“Arab Republic of Egypt...” IMF 2010).

Egypt's tax revenue to GDP ratio in 2010 was only $14.1 \%{ }^{3}$, which is relatively low compared to other Arab economies of similar size and nature, indicating the need to explore

\footnotetext{
${ }^{3}$ Some additional revenue is obtained from Suez Canal fees that is not included in the tax to GDP ratio, but the ratio
} 
policies to curb tax evasion and improve growth rates. Determining the extent to which the tax administration in Egypt is a significant constraint on private sector development is vital. A survey done by the World Bank ${ }^{4}$ in 2004 of 1000 enterprises found that tax-related issues were ranked as severe by almost $80 \%$ of the participants ("Egypt National Investment..." OECD 2006). Tax authority officials are known to exercise significant discretion in applying rules related to enterprise regulation and public service access. Furthermore, tax laws are excessively complex, thereby giving more room for the tax authority to act in discriminatory ways ("Egypt Country Profile..." 2004). These issues have led to an underreporting of income, tax evasion and, as a result, low revenues for the government.

Egypt's tax to GDP ratio falls well below that of other neighboring Arab countries with similar economies, such as Morocco (at 24\%), Tunisia (at 21\%) and Jordan (at 20\%). This further emphasizes Egypt's weak fiscal situation, possibly the result of high tax evasion. The problem, as with many others, was exacerbated by the revolution with the tax revenue as a percent of GDP falling to $13.2 \%$. This puts Egypt slightly below Columbia (13.3\%) and slightly above Uganda (13\%).

A World Bank Investment Climate Survey from 2004 found that access to finance and the associated cost are the main reasons constraining SME's investment and growth. Credit to the private sector has averaged around $40 \%$ of GDP in the past 5 years. Access to bank credit is needed to support the growth of the private sector, and could partially replace self-financing and the now absent FDI. A survey conducted by the Egyptian Center for Economic Studies found a mismatch between banks' excess lending capacity and the volume of loans provided to the 
private sector (Abdel-Kader 2006). The main source of financing was the firm's own funds (retained earnings) for a majority of firms (70\%).

\section{Egyptian Informal Sector}

With an estimated 8.2 million people in the informal sector (37\% of the workforce), there is great opportunity to broaden the tax base (World Bank 2010). A USAID report found that between the years of 1998 and 2006, the informal economy grew at an annual rate of 5.3\% (Alissa 2007). Furthermore, USAID found that about 40 to $60 \%$ of the cost of doing business results from the cumbersome regulatory framework that promotes the informal economy. Very few studies have explored the nature of the informal economy in Egypt. One notable study, led by economist Hernando de Soto was concluded in 2004 by the Institute for Liberty and Democracy. De Soto led years of fieldwork and analysis for the Egyptian government to determine how much of the economy operated "extralegally" (de Soto 2011).

His study concluded that the underground economy was the nation's biggest employer in 2004. He found that 9.6 million people worked in the extralegal sector while 6.8 million were employed in the private sector and 5.9 million in the public sector. Furthermore, $92 \%$ of Egyptians hold their property without normal legal title. Without any legal title to assets and real estate, entrepreneurs cannot leverage these assets as collateral for loans or investment capital. As a result, the majority of enterprises remain small and poor. de Soto estimated that the value of these extralegal business and property (in both the rural and urban parts of Egypt) to be $\$ 248$ billion at the time, 6 times greater than total savings and deposits in commercial banks in Egypt and 30 times more than the market value of the companies registered in the Cairo Stock Exchange at the time. The survey also identified the primary causes for extralegality in Egypt, 
notably the convoluted and redundant legal requirements for the various stages of a firm's development. The primary cause identified for the difficulty of expansion is the lack of access to credit. de Soto's findings have been confirmed by other Egyptian studies and surveys.

A World Bank Investment Climate Survey from 2004 found that access to finance and the associated cost are the main reasons constraining SME's investment and growth. Credit to the private sector has averaged around $40 \%$ of GDP in the past 5 years. Access to bank credit is needed to support the growth of the private sector, and could partially replace self-financing and the now absent FDI. A survey conducted by the Egyptian Center for Economic Studies found a mismatch between banks' excess lending capacity and the volume of loans provided to the private sector (Abdel-Kader 2006). The main source of financing was the firm's own funds (retained earnings) for a majority of firms $(70 \%)$.

Given these findings, we see that even after the 2005 tax reforms, evasion and informality remain key impediments for growth. Table 1 displays key indicators of the Egyptian economy before and after the 2005 tax reforms and the revolution. Inflation continues to rise and impede investment and confidence in the stability of the Egyptian economy. Furthermore, despite efforts to reduce public spending, public domestic debt has increased to $90 \%$ compared to an average of 50\% in the Middle East and North Africa (Achy 2010).

Comparisons within the MENA region and further abroad have shown the detrimental effects of wide tax evasion and informality found in Egypt. Given the difficult economic times, the revolution, and the inefficient tax system, new policies are needed to stimulate growth, increase revenues, and increase private sector access to credit. As explained below, this model 
accommodates the large amount of tax evasion and informality as it relates entry to the underground economy to tax rates and the need to access the banking system.

\section{b. Mauritius: Infrastructure Bottlenecks and Growth}

Mauritius is one of the great success stories of modern Africa. Despite weak growth in Europe, its main trading partner, the country has managed to sustain steady growth for the past 15 years, as indicated in the table below. ${ }^{5}$ In addition, the country has had steady growth rates in real per capita GDP, primarily because of it low population growth rate. Nonetheless, real growth has slowed and the country is looking for ways to increase growth.

\begin{tabular}{|l|r|r|r|r|r|r|r|r|r|r|r|r|r|r|}
\hline Mauritius & 2000 & 2001 & 2002 & 2003 & 2004 & 2005 & 2006 & 2007 & 2008 & 2009 & 2010 & 2011 & 2012 & 2013 \\
\hline Real GDP & 7.5 & 5.2 & 3.8 & 4.1 & 4.7 & 2.5 & 4.9 & 5.4 & 4.6 & 3.1 & 4.0 & 3.8 & 3.3 & 3.7 \\
\hline
\end{tabular}

Recent studies by both the International Monetary Fund and the African Development Bank have identified infrastructure deficiencies and related structural bottlenecks in the production system as having significant negative effects upon productivity and capacity utilization. According to the African Development Bank, “..., a US\$10billion infrastructure program has been announced to accompany the reform initiatives. A ten year Economic and Social Transformation Plan (ESTP) scheduled for approval in June 2014 translates the HIC agenda into strategic priority actions. The ESTP focuses on five priority areas (i) Increasing Competitiveness (ii) Developing infrastructure (iii) Strengthening human capital and social inclusion (iv) Enhancing Public Sector Efficiency and (v) Promoting Sustainable Environment."

${ }^{5}$ Source: http://www.indexmundi.com/g/g.aspx?c=mp\&v=66 (Mauritius GDP tables); IMFMAURITIUS 2014 ARTICLE IV CONSULTATION_STAFF REPORT; PRESS RELEASE; AND STATEMENT BY THE EXECUTIVE DIRECTOR FOR MAURITIUS. 
According to recent surveys, the private sector in Mauritius considers inadequate infrastructure to be a key problem facing enterprises wishing to do business in the country. It should be noted that Mauritius has the best telecommunication infrastructure in Africa. However, the ADB estimates that road transport congestion costs the economy an about $1.2 \%$ of GDP. Also, about $83 \%$ of the electricity used in the country is generated from imported fuel oil, thereby putting pressure in the balance of payments as well as undermining security. The government of Mauritius has therefore embarked upon an ambitious infrastructure program described below by the ADB.

"The objective of the GoM's infrastructure program is to develop a world class economic and social infrastructure to improve the delivery of public services and the competitiveness of the economy. About US\$4.5bn worth of investment has been programed for period 2013-2017 of which about $80 \%$ will go into economic sectors such as transport, utilities and communication. Financing will be through contribution from the Government (38\%), public enterprises (13\%), and private sources including FDI (22\%). About $26 \%$ will be met through additional local and foreign borrowing. Development partners are expected to contribute about US\$1.27billion (28\%) with the Bank as the lead partner (44\%) followed by AFD(18\%) and EU, Government of China, World Bank, EIB, BADEA and Government of India providing the rest. About US\$1.93billion of the program is expected to be implemented through the Public Private Partnership (PPP) modality including (i) The Road Decongestion Program Phase I worth US\$1.2 billion which is in advanced stages of negotiations. (ii) The CT Power Coal Project which has experienced delays due to controversies related to the contract and environmental license award (iii) The Light Rail Mass Transit System had a market sounding session (MSS) in 2012 (iv) Coal-fired Independent Power Plant and (vi) Lease contract in water sector."6

This resilience of the Mauritian economy, in the face of the overall world economic slowdown, has been at least partially the result of a series of fiscal programs. However, the government believes that the economy is operating below capacity. Closing this capacity gap will require addressing infrastructure shortfalls, thereby improving the efficiency of both particularly state-owned enterprises, as well as privately owned enterprises. More specifically,

\footnotetext{
${ }^{6}$ Source: Government of Mauritius (2013) Public Sector Investment Program
} 
the government wishes enhance the transport, energy, communications and water sectors' infrastructure, thereby improving overall productivity.

There are two key questions that need to be answered in investigating the role of these different types of infrastructure in enhancing the growth of the Mauritian economy. First, what are the efficiency enhancing property of different types of public infrastructure on different sectors of the economy? One would not necessarily expect that increased provision of a particular type of infrastructure would have uniform impacts across the economy. Second, if infrastructure does, indeed, enhance productivity, what is the optimal level of infrastructure spending?

\section{A General Equilibrium Specification}

In this section we develop the formal structure of a dynamic general equilibrium model that endogenously generates an underground economy. At the same time the model will permit the incorporation and analysis of productive public infrastructure. In addition, much of the structure of our model is designed to permit numerical implementation for Egypt and Mauritius. Our model has $n$ discrete time periods. All agents optimize in each period over a 2 period time horizon. That is, in period $t$ they optimize given prices for periods $t$ and $t+1$ and expectations for prices for the future after $t+1$. When period $t+2$ arrives, agents reoptimize for period $t+2$ and $t+3$, based on new information about period $t+2$.

\section{Production}

There are 8 factors of production and 3 types of financial assets:

$\begin{array}{llll}\text { 1-5 } & \text { Capital types } & 9 . & \text { Domestic currency } \\ \text { 6. } & \text { Urban labor } & 10 . & \text { Bank deposits } \\ \text { 7. } & \text { Rural labor } & 11 . & \text { Foreign currency } \\ \text { 8. } & \text { Land } & & \end{array}$


The five types of capital correspond to five aggregate nonagricultural productive sectors. An input-output matrix, $A_{t}$, is used to determine intermediate and final production in period $t$. In practice, matrix is $27 \times 27$ for each country. The first 26 rows and columns of the input-output matrix correspond to domestic production. The final row and column represents imports of intermediate goods, which are treated as a single aggregate commodity. Corresponding to each sector in the input-output matrix, sector-specific value added is produced using capital and urban labor for the nonagricultural sectors, and land and rural labor in agriculture.

The specific formulation of the firm's problem is as follows. Let $y_{K i}^{j}, y_{L i}^{j}$ be the inputs of capital and urban labor to the $j$ th nonagricultural sector in period $i$. Let $Y_{G i}$ be the outstanding stock of government infrastructure in period $i$. The production of value added in sector $j$ in period $i$ is then given by:

$$
v a_{j i}=v a_{j i}\left(y_{K i}^{j}, y_{L i}^{j}, Y_{G i}\right)
$$

where we suppose that public infrastructure may act as a productivity increment to private production.

Sector $j$ pays income taxes on inputs of capital and labor, given by $t_{K i j}, t_{L i j}$ respectively, in period $i$. The interpretation of these taxes is that the capital tax is a tax on firm profits, while the labor tax is a personal income tax that is withheld at source. It should be noted that the capital tax is equivalent to the standard formulation of the corporate income tax in economic models. The tax is not levied upon the stock of corporate capital, but on the returns to that capital, which is sector specific. There are no pure profits here, since production functions are constant returns to scale, and hence the corporate income tax is treated as a tax on returns to capital. 
We suppose that each type of sectoral capital is produced via a sector-specific investment technology that uses inputs of capital and labor to produce new capital. Investment is carried out by the private sector and is entirely financed by domestic borrowing

Let us define the following notation:

$C_{H i} \quad=$ The cost of producing the quantity $\mathrm{H}$ of capital of a particular type in period $i$.

$r_{i} \quad=$ The interest rate in period $i$.

$P_{K i} \quad=$ The return to capital in period $i$.

$P_{M i} \quad=$ The price of money in period $i$.

$\delta_{i} \quad=$ The rate of depreciation of capital.

Suppose, then, that the rental price of capital in period 1 is $P_{1}$. If $C_{H 1}$ is the cost-minimizing cost of producing the quantity of capital, $H_{1}$, then the cost of borrowing must equal the present value of the return on new capital. Hence:

$$
C_{H 1}=\sum_{i=2}^{n}\left[\frac{P_{K i}(1-\delta)^{i-2} H_{1}}{\prod_{j=1}^{i-1}\left(1+r_{j}\right)}\right]
$$

where $r_{j}$ is the interest rate in period $\mathrm{j}$, given by:

$$
r_{j}=1 / P_{B j}
$$

where $r_{j}$ is the price of a bond in period $j$. The tax on capital is implicitly included in the investment problem, as capital taxes are paid on capital as an input to production.

The to invest depends not only on the variables in the above equation, but also upon the decision the firm makes as to whether it should pay taxes. This decision determines the firm's entry into the underground economy. We assume that the firm's decision is based upon a 
comparison of the tax rate on capital with the rate of return on new capital. Formally, suppose that we were in a two period world. Suppose that:

$$
\frac{P_{K 2}}{1+r_{1}} \geq t_{K 1}
$$

that is, the present value of the return on one unit of new capital is greater than the current tax rate on capital. In this case we assume the investor pays the full tax rate on capital inputs.

Suppose, on the other hand, that:

$$
\frac{P_{K 2}}{1+r_{1}} \leq t_{K 1}
$$

Here the discounted rate of return is less than the tax rate. The extent to which the firm goes into the underground economy is determined by the gap between the tax rate and the rate of return to investment. That is, the firm pays a tax rate of $\bar{t}_{K 1}$ where:

$$
\bar{t}_{K 1}=t_{K 1}\left[1-\left(\frac{t_{K 1}-\frac{P_{K 2}}{1+r_{2}}}{t_{K 1}}\right)\right]^{\alpha}
$$

Here $0 \leq \alpha$ and higher values of $\alpha$ lead to lower values of taxes actually paid. That is, the ratio $\frac{\bar{t}_{K 1}}{t_{K 1}}$ reflects the share of the sector that operates in the above ground economy. Hence $\alpha$ represents a firm-specific behavioral variable. An "honest" firm would set $\alpha=0$, while a firm that is prone to evasion would have a high value for $\alpha$.

We should note that a firm's decision to evade taxes is based upon a comparison of the marginal return to capital with the tax rate. ${ }^{7}$ Hence a firm may be quite capital intensive, i.e.,

\footnotetext{
${ }^{7}$ In the presence of corruption in tax administration, the effective tax rate takes into account evasion and bribes. The firms will compare marginal return to capital with effective tax rate in
} 
have a large stock of existing capital, yet have a low marginal return to new capital and hence be predisposed to evading taxes. Thus, for example, an "old" industrial firm might be a tax evader, while being relatively capital intensive. A service sector firm, while being relatively labor intensive, might have a high marginal rate of return to new capital and hence not wish to evade taxes. Thus simply looking at relative capital intensities will not allow us to predict the degrees of tax evasions different firms will choose. It is, however, the case that evasion in our model is driven by a focus on the capital income tax and firms' optimizing their avoidance of payments of

that tax. If, for example, we also incorporated evasion of other taxes, for example, payments of the personal income tax, then this might alter the extent to which the service sector dominates tax evasion. The service sector, which sees little benefit in paying the capital income tax, tends to evade it, while manufacturing tends to pay it, given their need to invest.

\section{Banking}

We will suppose that there is one bank for each nonagricultural sector of the economy. There are 5 such sectors, and hence 5 banks, corresponding to each of the aggregate capital stocks. Each bank lends primarily to the sector with which it is associated. The banks are, however, not fully specialized in the sector they correspond to. We make the simplifying assumption that each bank holds a fixed share of the outstanding debt of its particular sector. It then holds additional fixed shares of the debt of each of the remaining sectors. We make this assumption of diversification of assets in order to allow for a situation in which a firm that evades taxes, and thereby enters the underground economy, might receive varying degrees of credit rationing from the different banks to which it applies for loans.

the presence of corruption. 
Our premise is that banks have no direct way of knowing whether specific firms operate in the underground economy. We assume that banks only care about the amount of capital that they estimate the firm may have. If the firm defaults on its loan, then this represents the best estimate of the amount that the bank could seize. The bank would, presumably, be willing to lend an amount equal to at least the estimated firm capital.

We assume the borrower is required to show the bank his tax returns in order to obtain a loan. There is a single, flat corporate tax rate that the borrowing firm faces. Hence, suppose that $T_{K 1}$ represents taxes actually paid by the borrower in period 1 . This is known to the bank, as the potential borrower is required to present his tax returns. Thus if the borrower fully complied with his tax obligation, and hence carried out no underground activity, the value of his capital, $\hat{K}_{1}$, would be given by:

$$
\hat{K}_{1}=\frac{T_{K 1}}{t_{K 1}}
$$

In this case the bank lends an amount $L_{1}$, where $L_{1}<C_{H 1}$, as the bank would not be able to seize the full value of the loan in the case of a default. The situation we have described would, in the case of perfect certainty, have credit rationing when the estimated value of the firm's capital is less than its loan request. If the firm's capital is greater than its loan request, there would be no credit rationing.

In a more realistic case of uncertainty about both the true value of the firm, as well as about the bank's own ability to seize the firm, one might expect the lending process to be somewhat different. Accordingly, we will suppose that a simple functional form determines bank lending as a function of the amount requested as well as the estimated value of the firm's capital. We define the amount the bank lends, $L_{1}$, as: 


$$
L_{1}=C_{H 1}\left[\frac{\frac{\hat{K}_{1}}{C_{H 1}}}{1+\frac{\hat{K}_{1}}{C_{H 1}}}\right]^{\gamma}=C_{H 1}\left[\frac{\hat{K}_{1}}{C_{H 1}+\hat{K}_{1}}\right]
$$

Here $\gamma$ represents a measure of risk aversion by the bank. If $\gamma=0$, there are no credit restrictions, and the bank ignores estimates of the borrower's estimated net worth. As $\gamma$ rises, the bank increasingly restricts lending if the term in brackets is less than 1 . Thus if a firm operates entirely in the underground economy it will not be able to borrow to finance investment. If banks are highly risk averse, they will never lend more than a firm's estimated net worth, which is based on its tax return. This tax return therefore represents all the information the bank needs in order to determine its response to a request for a loan.

\section{Consumption}

There are two types of consumers, representing rural and urban labor. We suppose that the two consumer classes have differing Cobb-Douglas demands and endowments. The consumers maximize intertemporal utility functions, which have as arguments the levels of consumption and leisure in each of the two periods.

Formally, the consumer's problem is then given by equation $5 .{ }^{8}$ The definition of the notation follows.

$$
\operatorname{Max} U(x), x=\left(x_{1}, x_{L u 1}, x_{L r 1}, x_{2}, x_{L u 2}, x_{L r 2}\right)
$$

such that:

$$
\begin{aligned}
& \left(1+t_{i}\right) P_{i} x_{i}+P_{L u i} x_{L u i}+p_{L r i} x_{L r i}+P_{M i} x_{M i}+P_{B i} x_{B i}+e_{i} P_{B f i} x_{B f i}=C_{i} \\
& P_{K 1} K_{0}+P_{A 1} A_{0}+P_{L u 1} L_{u 1}+P_{L r 1} L_{r 1}+P_{M 1} M_{0}+r_{0} B_{0}+P_{B 1} B_{0}+e_{1} P_{B F 1} B_{F 0}+T R_{1}=N_{1}
\end{aligned}
$$

\footnotetext{
${ }^{8}$ See Feltenstein and Shamloo (2012) for a discussion of this modeling approach.
} 


$$
\begin{aligned}
& P_{K 2}(1-\delta) K_{0}+P_{A 2} A_{0}+P_{L u 2} L_{u 2}+P_{L r 2} L_{r 2}+P_{M 2} x_{M 1}+r_{1} x_{B 1}+e_{2} P_{B F 2} x_{B F 1}+T R_{2}=N_{2} \\
& C_{i}=N_{i} \\
& \log P_{B i} x_{B i}-\log e_{i} P_{B F i} x_{B F i}=\alpha+\beta\left(\log r_{i}-\log \frac{e_{i+1}}{e_{i}} r_{F i}\right) \\
& \log \left(L_{u i} / L_{r i}\right)=a_{1}+a_{2} \log \frac{P_{L u i}-P_{L r i}}{P_{L u i}+P_{L r i}} \\
& \log P_{M i} x_{M i}=a+b \log \left(1+t_{i}\right) P_{i} x_{i} \\
& P_{B 2} x_{B 2}=d_{0}+d_{1}\left(1+t_{2}\right) P_{2} x_{2}+d_{2}\left[\frac{r_{2}-\pi_{2}}{1+\pi_{2}}\right]
\end{aligned}
$$

where:

$P_{i}=$ price vector of consumption goods in period $i$.

$x_{i}=$ vector of consumption in period $i$.

$C_{i}=$ value of aggregate consumption in period $i$ (including purchases of financial assets).

$N_{i}=$ aggregate income in period $i$ (including potential income from the sale of real and financial assets).

$t_{i}=$ vector of value added tax rates in period $i$.

$P_{\text {Lui }}=$ price of urban labor in period $i$.

$L_{u i}=$ allocation of total labor to urban labor in period $i$.

$x_{L u i}=$ demand for urban leisure in period $i$.

$P_{L r i}=$ price of rural labor in period $i$.

$L_{r i}=$ allocation of total labor to rural labor in period $i$.

$x_{L r i}=$ demand for rural leisure in period $i$.

$a_{2}=$ elasticity of rural/urban migration.

$P_{K i}=$ price of capital in period $i$. 
$K_{0}=$ initial holding of capital.

$P_{A i}=$ price of land in period $i$.

$A_{0}=$ initial holding of land.

$\delta=$ rate of depreciation of capital.

$P_{M i}=$ price of money in period $i$. Money in period 1 is the numeraire.

$x_{M i}=$ holdings of money in period $i$.

$P_{B i}=$ discount price of a certificate of deposit in period $i$.

$\pi_{i}=$ domestic rate of inflation in period $i$.

$r_{i}, r_{F i}=$ the domestic and foreign interest rates in period $i$.

$x_{B i}=$ quantity of bank deposits, that is, CD's in period $i$.

$e_{i}=$ the exchange rate in terms of units of domestic currency per unit of foreign currency in period $i$.

$x_{B F i}=$ quantity of foreign currency held in period $i$.

$T R_{i}=$ transfer payments from the government in period $i$.

$\mathrm{a}, \mathrm{b}, \alpha, \beta=$ estimated constants.

$d_{i}=$ constants estimated from model simulations.

\section{The Government}

The government collects personal income, corporate profit, and value-added taxes, as well as import duties. It pays for the production of infrastructure (capital expenditure), wages and spending on goods and services (current expenditure), public goods, as well as for subsidies. In addition, the government must cover both domestic and foreign interest obligations on public debt. The resulting deficit is financed by a combination of monetary expansion, as well as domestic and foreign borrowing 


\section{The Foreign Sector}

The foreign sector is represented by a simple export equation in which aggregate demand for exports is determined by domestic and foreign price indices, as well as world income. The specific form of the export equation is:

$$
\Delta X_{n 0}=\sigma_{1}\left[\frac{\pi_{1}}{\Delta e_{i}+\pi_{F i}}\right]+\sigma_{2} \Delta y_{w i}
$$

where the left-hand side of the equation represents the change in the dollar value of exports in period $i, \pi_{\mathrm{i}}$ is inflation in the domestic price index, $\Delta e_{i}$ is the percentage change in the exchange rate, and $\pi_{F i}$ is the foreign rate of inflation. Also, $\Delta y_{w i}$ represents the percentage change in world income, denominated in dollars. Finally, $\sigma_{1}$ and $\sigma_{2}$ are corresponding elasticities.

Imports are treated as a single aggregate good produced by the foreign sector. Consumption demand for imports is determined as part of the consumer's demand given by equation (5), in which consumers have an elasticity of demand for imported goods. Thus imports are both intermediate and final goods, with intermediate demand being generated by the input-output matrix and final demand coming from consumer optimization.

\section{Mauritius: Infrastructure Estimation}

\section{Model Specification}

We assume that cost of production depends on input prices and infrastructure stock. The cost function of the $\mathrm{k}^{\text {th }}$ sector can be written as $C_{k}\left(w, r, q_{k}, E_{p}, E_{v}, T_{p}, T_{v}\right)$ where, w is labor's return or wage rate, $\mathrm{r}$ is capital's return or interest rate, $q_{k}$ is sectoral output, $E_{p}$ is the public electricity infrastructure stock, $E_{v}$ is the private electricity infrastructure stock, $T_{p}$ is the public transportation and communication infrastructure stock, and $T_{v}$ is the private transportation and communication infrastructure stock. $C_{k}$ is twice continuously differentiable and has other 
standard properties of cost functions. As discussed by Christensen, Jorgenson, \& Lau (1973), and Berndt \& Wood (1975) it can be written in following trans-log form:

$\ln (C)=\alpha_{0}+\sum_{i} \alpha_{i} \ln \left(x_{i}\right)+\sum_{j} \sum_{i} \beta_{i j} \ln \left(x_{i}\right) \ln \left(x_{j}\right)+\frac{1}{2} \sum_{j} \beta_{i i} \ln \left(x_{i}\right)^{2}$

Differentiating (6) with respect to $\ln (\mathrm{w})$ and $\ln (\mathrm{r})$, and using Shephard's lemma we get:

$$
\begin{gathered}
X_{l} \frac{w}{C}=\alpha_{w}+\beta_{w r} \ln (r)+\beta_{w q} \ln (q)+\beta_{w E p} \ln \left(E_{p}\right)+\beta_{w E v} \ln \left(E_{v}\right)+\beta_{w T p} \ln \left(T_{p}\right) \\
\quad+\beta_{w T v} \ln \left(T_{v}\right)+\beta_{w w} \ln (w) \ldots \ldots \ldots \ldots(7)
\end{gathered}
$$

Where $X_{1}$ and $X_{k}$ are labor and capital input demands respectively. Dividing (7) by (8) and after further simplification we get:

$\ln (q)=\eta_{0}+\eta_{r} \ln (r)+\eta_{w} \ln (w)+\eta_{E p} \ln \left(E_{p}\right)+\eta_{E v} \ln \left(E_{v}\right)+\eta_{T p} \ln \left(T_{p}\right)+\eta_{T v} \ln \left(T_{v}\right) .$.

Where,

$$
\eta_{E p}=\frac{\left[X_{k} r \beta_{w E p}-X_{l} w \beta_{r E p}\right]}{\left[X_{l} w \beta_{r q}-X_{k} r \beta_{w q}\right]} \quad \text { and } \quad \eta_{T p}=\frac{\left[X_{k} r \beta_{w T p}-X_{l} w \beta_{r T p}\right]}{\left[X_{l} w \beta_{r q}-X_{k} r \beta_{w q}\right]}
$$

are elasticities for public electricity and water supply infrastructure, and public transportation and communication infrastructure respectively.

Equation (9) can be estimated by the following equation:

$$
\begin{aligned}
\ln (q)_{t}=\gamma_{0}+ & \gamma_{1} \ln (r)_{t}+\gamma_{2} \ln (w)_{t}+\gamma_{3} \ln \left(E_{p}\right)_{t}+\gamma_{4} \ln \left(E_{v}\right)_{t}+\gamma_{5} \ln \left(T_{p}\right)_{t} \\
& +\gamma_{6} \ln \left(T_{v}\right)_{t}+\varepsilon_{t} \ldots \ldots \ldots(10)
\end{aligned}
$$

\section{Data}

In our estimation we assume sector specific wage rates and a single interest rate for all industry groups. Our measure of interest is the annual bank rate of Mauritius which is simple 
average of weighted average yield per annum of 91-day, 182-day, 273-day, and 364-day Government of Mauritius Treasury Bills. We obtain data for 1999 to 2013 from the Monthly Statistical Bulletin of the Bank of Mauritius, various issues. For 1987 to 1998, we use end of period (December) bank rate reported by Jankee (1999). Our measure of wage rate is the average monthly earnings by industrial groups computed from the Survey of Employment and Earnings in Large (employing 10 or more) Establishments by Statistics Mauritius. We obtain wage data for 1987 to 1990 from IMF (1996); and for rest of the period, data are obtained from Labor Force Historical Series of Statistics Mauritius. Average monthly earnings are reported for more disaggregated industry groups since 2000. Therefore, we calculate the weighted average of monthly earnings, weighted by sectoral employment in large establishments, to obtain wage rates for our aggregated industry groups. Nominal wages are then deflated by annual Consumer Price Index to obtain real wages in constant 2006 prices.

\section{Capital Stock Calculation}

We use the following perpetual inventory method to calculate capital stock:

$K_{t}=(1-\delta) K_{t-1}+I_{t-1}$

Where, $K_{t}$ is the capital stock available at the beginning of period t, $\delta$ is the rate of depreciation, and $I_{t-1}$ is the gross fixed capital formation in period $\mathrm{t}-1$. Repeated substitution of $K_{t-1}$ in equation (6) yields:

$K_{t}=\sum_{i=0}^{\infty}(1-\delta)^{i} I_{t-(i+1)}$

Equation (12) suggests that capital stock data can be calculated from gross fixed capital formation data if the initial capital stock $K_{0}$ is known. Harberger (1978) suggests using steady state conditions from neo-classical growth literature to figure out initial capital stock. Since 
growth rate of capital equals growth rate of output in steady state, $K_{0}$ can be calculated from the following formula:

$K_{0}=\frac{I_{0}}{g_{G D P}+\delta}$

Harberger further suggests using three year average investment and three year average GNP growth rate to eliminate short run fluctuations. Vikram \& Dhareshwar (1993) propose an alternative econometric approach for calculating $I_{0}$. They run a linear regression of $\log$ of investment over time, and use first period fitted value as $I_{0}$. In our calculation we employ both average and fitted values as appropriate for different industry groups depending on data. In a special case for initial capital stock of mining we use a slightly different approach since gross fixed capital formation in mining industry was near zero for a certain period of time. We use gross operating surplus of mining industry in first available year to calculate capital stock of mining industry in that year, and then iterate backward using equation (12) to get the initial capital stock. We assume a constant depreciation rate of $5 \%$ for all industries.

Gross domestic fixed capital formation data are collected from the National Accounts Historical Series of Statistics Mauritius. We compile four different national accounts series from 1976 to 1998,1990 to 2002,1999 to 2010 , and 2006 to 2013 to get a time series of public and private gross fixed capital formation from 1987 to 2013. Since national accounting standards has evolved over time and more recent data are reported at more disaggregated level, it is difficult to generate a uniform time series data. For our purpose we aggregate sectors in ten broad industry categories. Details of sectoral aggregation are presented in Table $2 \mathrm{a}$ while Table $2 \mathrm{~b}$ gives macro aggregates for Mauritius.

We first calculate total capital stock series for different industries using total gross 
domestic fixed capital formation data, and separately calculate private capital stocks for industry groups using gross domestic private fixed capital formation data. We then subtract private capital stocks from total capital stocks to generate public capital stock series for different industry groups.

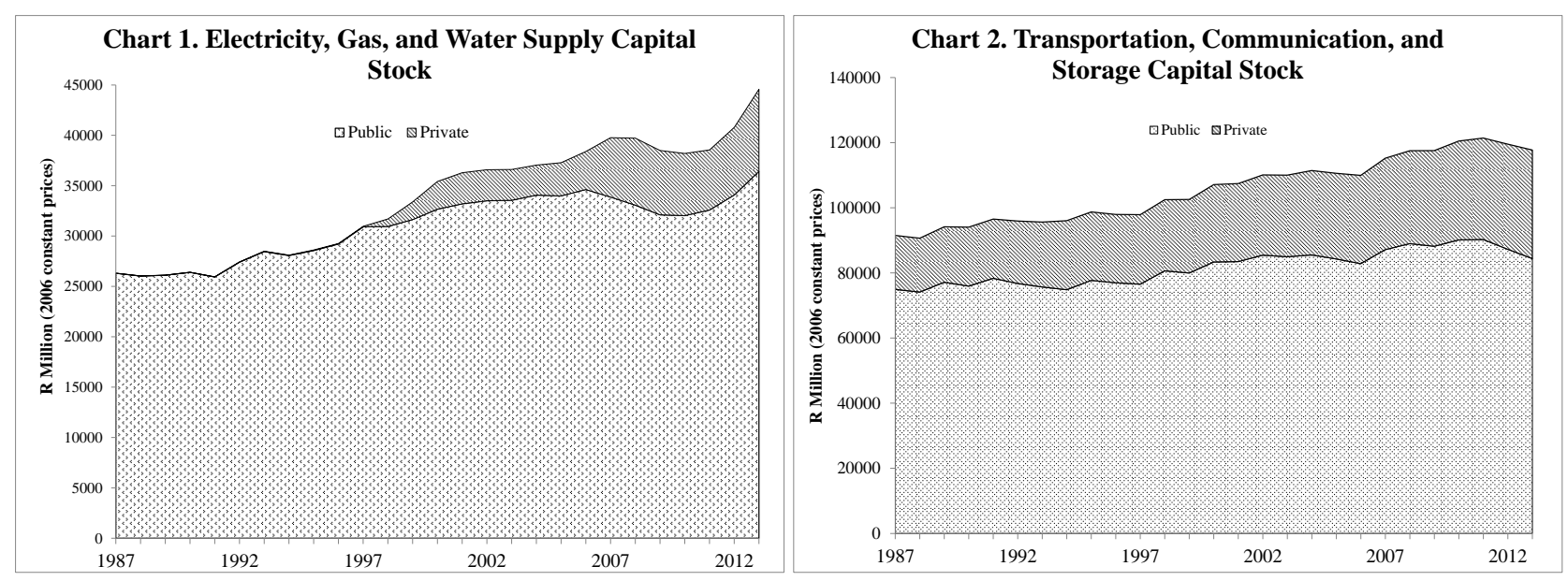

Chart -1 and Chart -2 show electricity, gas, and water supply capital stocks, and transportation, communication, and storage capital stock respectively from 1987 to 2013 . The charts demonstrate that the major shares of electricity and transportation infrastructure stocks in Mauritius belong to the public sector. 
Table 2a. Aggregation of Industrial Sectors

\begin{tabular}{|c|c|c|c|c|}
\hline \multicolumn{2}{|r|}{ 1987-1991 } & \multicolumn{2}{|r|}{ 1992-2005 } & 2006-2013 \\
\hline 1. & $\begin{array}{l}\text { Agriculture, hunting, forestry } \\
\text { and fishing }\end{array}$ & 1. & $\begin{array}{l}\text { Agriculture, hunting, forestry and } \\
\text { fishing }\end{array}$ & Agriculture, forestry and fishing \\
\hline 2. & Mining and quarrying & 2. & Mining and quarrying & Mining and quarrying \\
\hline 3. & Manufacturing & 3. & Manufacturing & Manufacturing \\
\hline 4. & $\begin{array}{l}\text { Electricity, gas and water } \\
\text { supply }\end{array}$ & 4. & Electricity, gas and water supply & $\begin{array}{l}\text { 4. Electricity, gas, steam and air conditioning } \\
\text { supply } \\
\text { 5. Water supply, sewerage, waste management } \\
\text { and remediation }\end{array}$ \\
\hline 5. & Construction & 5. & Construction & Construction \\
\hline 6. & $\begin{array}{l}\text { Wholesale \& retail trade, } \\
\text { restaurants \& hotels }\end{array}$ & 6. & $\begin{array}{l}\text { Wholesale \& retail trade; repair of } \\
\text { motor vehicles, motorcycles, } \\
\text { personal and household goods } \\
\text { Hotels and restaurants }\end{array}$ & Accommodation and food service activities \\
\hline 7. & $\begin{array}{l}\text { Transport , storage and } \\
\text { communications }\end{array}$ & 8. & $\begin{array}{l}\text { Transport , storage and } \\
\text { communications }\end{array}$ & $\begin{array}{ll}\text { 9. } & \text { Transportation and storage } \\
\text { 10. } & \text { Information and communication }\end{array}$ \\
\hline 8. & $\begin{array}{l}\text { Financing, insurance, real estate } \\
\text { and business }\end{array}$ & $\begin{array}{l}9 . \\
10 .\end{array}$ & $\begin{array}{l}\text { Financial intermediation } \\
\text { Real estate, renting and business } \\
\text { activities }\end{array}$ & $\begin{array}{l}\text { 11. Financial intermediation } \\
\text { 12. Real estate activities }\end{array}$ \\
\hline 9. & $\begin{array}{l}\text { Producers of Government } \\
\text { services }\end{array}$ & 11. & $\begin{array}{l}\text { Public administration and defense; } \\
\text { compulsory social security }\end{array}$ & $\begin{array}{lll}\text { 13. Public administration and defense; } \\
\text { compulsory social security }\end{array}$ \\
\hline 10. & Other services & $\begin{array}{l}12 . \\
13 . \\
14 .\end{array}$ & $\begin{array}{l}\text { Education } \\
\text { Health and social work } \\
\text { Other community, social and } \\
\text { personal service activities and } \\
\text { private households with employed } \\
\text { persons }\end{array}$ & $\begin{array}{l}\text { 14. Education } \\
\text { 15. Human health and social work activities } \\
\text { 16. Professional, scientific and technical } \\
\text { activities } \\
\text { 17. Administrative and support service activities } \\
\text { 18. Arts, entertainment and recreation } \\
\text { 19. Other service activities }\end{array}$ \\
\hline
\end{tabular}


Table $2 b$ - Mauritius Economy

\begin{tabular}{|c|c|c|c|c|c|c|c|}
\hline Year & $\begin{array}{r}\text { Real } \\
\text { GDP } \\
\text { Growth }\end{array}$ & $\begin{array}{r}\text { GDFCF } \\
(\% \text { of } \\
\text { GDP) }\end{array}$ & $\begin{array}{r}\text { Public } \\
\text { GDFCF } \\
\text { (\% of } \\
\text { GDP) }\end{array}$ & $\begin{array}{r}\text { Revenue } \\
\text { (\% of } \\
\text { GDP) }\end{array}$ & $\begin{array}{r}\text { Budget } \\
\text { Deficit } \\
\text { (\% of } \\
\text { GDP) }\end{array}$ & $\begin{array}{r}\text { Foreign } \\
\text { Financing } \\
(\mathrm{Net}) \\
(\% \text { of GDP })\end{array}$ & $\begin{array}{r}\text { Domestic } \\
\text { Financing } \\
(\mathrm{Net}) \\
(\% \text { of GDP })\end{array}$ \\
\hline 2000 & 7.30 & 22.54 & 6.31 & 19.20 & -3.52 & -0.42 & 3.94 \\
\hline 2001 & 2.56 & 22.31 & 6.94 & 16.97 & -6.16 & -2.67 & 8.83 \\
\hline 2002 & 1.14 & 21.42 & 6.74 & 17.43 & -5.73 & 0.68 & 12.68 \\
\hline 2003 & 5.71 & 22.49 & 8.62 & 18.67 & -5.69 & 0.15 & 5.54 \\
\hline 2004 & 4.14 & 21.71 & 6.52 & 18.61 & -4.91 & -0.27 & 5.18 \\
\hline 2005 & 1.36 & 21.48 & 6.22 & 18.84 & -4.72 & 0.25 & 4.46 \\
\hline 2006 & 4.50 & 24.22 & 7.52 & 18.37 & -4.85 & -0.54 & 5.38 \\
\hline 2007 & 5.89 & 25.10 & 5.37 & 17.28 & -3.87 & 1.83 & 2.04 \\
\hline 2008 & 5.49 & 24.62 & 4.14 & 19.40 & -2.52 & -0.09 & 3.12 \\
\hline 2009 & 3.07 & 26.36 & 6.60 & 22.03 & -2.99 & 1.24 & 2.35 \\
\hline 2010 & 4.04 & 24.87 & 6.10 & 21.89 & -3.20 & 1.82 & 1.57 \\
\hline 2011 & 3.95 & 24.02 & 5.54 & 21.43 & -3.20 & 1.72 & 2.41 \\
\hline 2012 & 3.14 & 23.02 & 5.53 & 21.45 & -1.77 & 0.87 & 1.31 \\
\hline 2013 & 3.20 & 21.02 & 5.01 & 21.35 & -3.50 & 2.95 & 1.99 \\
\hline
\end{tabular}

Source: Authors' calculation from Statistics Mauritius Data 


\section{Estimation}

We estimate equation (10) for different industry groups. However, we first need to check time series properties of the data to avoid spurious regression. For meaningful estimation, it requires time series data to be stationary or variables to be cointegrated. We performed Augmented Dickey - Fuller test and Pillips - Perron test to investigate the presence of a unit root. Lag lengths are determined using Akaike and Schwartz information criterions. Results of unit root tests are presented in Table 3. It turns out that except for agricultural GDP, construction wages, and other services wages, all other variables contain a unit root, and hence are not stationary. We, therefore, need to examine whether the variables are cointegrated. We performed Johansen cointegration test for the variables listed in equation (9) and found at least one cointegrating relationship for each industry group. Results of the cointegration tests suggest that estimates of equation (10) can be treated as long run relationships between respective variables. However, the estimation for the agricultural sector is not valid since the order of integration for independent and dependent variables are different.

We also need to take care of serial correlation in our regression. We performed Durbin Watson and Breusch-Godfrey tests to check for serial correlation. It appears that we have serial correlation problems for the mining, manufacturing, wholesale $\&$ trade sectors. We use a Prais Winsten regression for these industry groups. Estimation results of equation (10) are presented in Table 4. 
Table 3. Augmented Dickey Fuller and Phillips-Perron Test Statistics for Unit Root Test

\begin{tabular}{|c|c|c|c|c|c|c|c|c|c|c|}
\hline \multirow[b]{3}{*}{ Variables } & \multirow[b]{3}{*}{ Lags } & \multicolumn{4}{|c|}{ Level } & \multicolumn{4}{|c|}{ First Difference } & \multirow[b]{3}{*}{$\mathrm{I}()}$. \\
\hline & & \multicolumn{2}{|c|}{ No Trend } & \multicolumn{2}{|c|}{ Trend } & \multicolumn{2}{|c|}{ No Trend } & \multicolumn{2}{|c|}{ Trend } & \\
\hline & & $\mathrm{ADF}$ & $\mathrm{PP}$ & $\mathrm{ADF}$ & $\mathrm{PP}$ & $\mathrm{ADF}$ & $\mathrm{PP}$ & $\mathrm{ADF}$ & $\mathrm{PP}$ & \\
\hline $\ln \left(\mathrm{Q}_{\mathrm{agri}}\right)$ & 0 & $-3.45 * *$ & $-18.439 * * *$ & $-5.437 * * *$ & $-28.727 * * *$ & $-6.736 * * *$ & $-33.05 * * *$ & $-6.619 * * *$ & $-33.194 * * *$ & $\mathrm{I}(0)$ \\
\hline $\ln \left(\mathrm{Q}_{\text {mining }}\right)$ & 2 & -0.422 & -0.109 & -2.272 & -3.883 & -1.959 & $-11.249 *$ & -2.08 & -14.885 & $\mathrm{I}(1)$ \\
\hline $\ln \left(\mathrm{Q}_{\text {manuf }}\right)$ & 1 & $-2.732 *$ & -1.776 & -1.345 & -2.396 & -2.081 & $-14.996^{* *}$ & -2.842 & $-23.881 * * *$ & $\mathrm{I}(1)$ \\
\hline $\ln \left(\mathrm{Q}_{\text {const }}\right)$ & 2 & -1.72 & -1.92 & -2.091 & -9.153 & $-1.993 *$ & $-10.966 *$ & -2.385 & -14.37 & $\mathrm{I}(1)$ \\
\hline $\ln \left(Q_{\text {trade }}\right)$ & 1 & -1.853 & -1.017 & -1.133 & -4.955 & $-3.238 * *$ & $-15.969 * *$ & $-4.254 * *$ & $-20.899 * *$ & $\mathrm{I}(1)$ \\
\hline $\ln \left(\mathrm{Q}_{\text {finance }}\right)$ & 1 & -0.784 & -0.163 & -1.772 & -10.269 & $-5.076 * * *$ & $-28.174 * * *$ & $-5.187 * * *$ & $-28.216 * * *$ & $\mathrm{I}(1)$ \\
\hline $\ln \left(Q_{\text {other }}\right)$ & 2 & -1.727 & -0.336 & $-3.542 *$ & -5.597 & $-2.715^{*}$ & $-15.003 * *$ & -3.211 & $-17.339 *$ & $\mathrm{I}(1)$ \\
\hline $\ln \left(\mathrm{w}_{\text {agri }}\right)$ & 1 & -0.101 & -0.529 & -2.159 & -9.499 & $-3.775 * * *$ & $-27.099 * * *$ & $-3.732 * *$ & $-27.082 * * *$ & $\mathrm{I}(1)$ \\
\hline $\ln \left(\mathrm{W}_{\text {mining }}\right)$ & 1 & -1.901 & -6.258 & -2.022 & -5.747 & -2.477 & $-24.563 * * *$ & $-3.283^{*}$ & $-27.991 * * *$ & $\mathrm{I}(1)$ \\
\hline $\ln \left(\mathrm{w}_{\text {manuf }}\right)$ & 1 & -0.406 & -2.298 & -3.032 & -10.932 & $-3.564 * *$ & $-27.873 * * *$ & $-3.973 * *$ & $-28.398 * * *$ & $\mathrm{I}(1)$ \\
\hline $\ln \left(\mathrm{w}_{\text {const }}\right)$ & 1 & -0.748 & -2.885 & $-4.464 * * *$ & $-21.699 * *$ & $-7.493 * * *$ & $-22.87 * * *$ & $-7.422 * * *$ & $-22.749 * * *$ & $\mathrm{I}(0)$ \\
\hline $\ln \left(\mathrm{w}_{\text {trade }}\right)$ & 1 & -1.777 & -2.853 & -1.741 & -8.782 & $-3.935 * * *$ & $-28.349 * * *$ & $-4.368 * *$ & $-29.691 * * *$ & $\mathrm{I}(1)$ \\
\hline $\ln \left(\mathrm{w}_{\text {finance }}\right)$ & 3 & 1.273 & 1.884 & -2.063 & -6.663 & -0.334 & $-33.522 * * *$ & -0.402 & $-35.882 * * *$ & $\mathrm{I}(1)$ \\
\hline $\ln \left(\mathrm{w}_{\text {other }}\right)$ & 3 & -0.596 & -0.892 & -2.179 & $-23.636 * * *$ & $-4.341 *$ & $-29.059 * * *$ & $-4.227 * *$ & $-29.046 * * *$ & $\mathrm{I}(0)$ \\
\hline $\ln (r)$ & 1 & -0.267 & -1.969 & -1.797 & -10.362 & $-4.011 * * *$ & $-28.366 * * *$ & $-4.271 * *$ & $-29.68 * * *$ & $\mathrm{I}(1)$ \\
\hline $\ln \left(E_{\text {pub }}\right)$ & 1 & -0.842 & -0.848 & -2.053 & -5.286 & -2.275 & $-16.734 * *$ & -2.123 & $-16.712 *$ & $\mathrm{I}(1)$ \\
\hline $\ln \left(\mathrm{T}_{\mathrm{pub}}\right)$ & 1 & -1.44 & -2.461 & -1.655 & -12.88 & $-2.999 *$ & $-31.144 * * *$ & -2.959 & $-31.457 * * *$ & $\mathrm{I}(1)$ \\
\hline $\ln \left(E_{p v t}\right)$ & 1 & -1.699 & -1.889 & -1.553 & -4.313 & $-2.805^{*}$ & $-18.118 * * *$ & -2.943 & $-19.247 * *$ & $\mathrm{I}(1)$ \\
\hline $\ln \left(\mathrm{T}_{\mathrm{pvt}}\right)$ & 1 & -0.524 & 0.013 & -2.994 & -13.577 & $-3.861 * * *$ & $-27.678 * * *$ & $-3.8 * *$ & $-27.544 * * *$ & $\mathrm{I}(1)$ \\
\hline
\end{tabular}




\section{Results}

Results show that there is economically and statistically significant relationship between sectoral output and public infrastructure. Outputs of manufacturing, wholesale $\&$ trade, financial services, and other services are positively related with public electricity infrastructure stock. Similarly, the public transportation and communication capital stock has statistically significant positive effects on construction, financial services, and other services. Based on these estimation results, we may conclude that economic growth in Mauritius is positively associated with public infrastructure facilities.

Table 4. Serial Correlation Corrected Infrastructure Elasticities

\begin{tabular}{lccccccc}
\hline & $(1)$ & $(2)$ & $(3)$ & $(4)$ & $(5)$ & $(6)$ & $(7)$ \\
VARIABLES & Agri. & Mining & Manuf. & $\begin{array}{c}\text { Constr. } \\
\text { Trade }\end{array}$ & $\begin{array}{c}\text { Finance } \\
\text { Other }\end{array}$ \\
\hline \multirow{2}{*}{ Log Wage } & 0.268 & -0.143 & 0.135 & -0.121 & 0.111 & -0.0455 & 0.0927 \\
& $(0.284)$ & $(0.199)$ & $(0.229)$ & $(0.220)$ & $(0.178)$ & $(0.113)$ & $(0.102)$ \\
Log Interest Rate & -0.0627 & 0.0963 & 0.0173 & 0.0614 & 0.0383 & -0.0176 & -0.00185 \\
& $(0.0676)$ & $(0.129)$ & $(0.0274)$ & $(0.0460)$ & $(0.0275)$ & $(0.0400)$ & $(0.0222)$ \\
Log Public Electricity & 0.193 & 0.536 & $0.784 * *$ & -0.0991 & $0.677 * *$ & $0.537 *$ & $0.344 *$ \\
& $(0.710)$ & $(1.472)$ & $(0.277)$ & $(0.401)$ & $(0.285)$ & $(0.300)$ & $(0.193)$ \\
Log Public & 0.886 & -1.094 & 0.548 & $2.393 * * *$ & 0.553 & $1.243 * *$ & $0.650^{* *}$ \\
Transportation & $(0.946)$ & $(1.678)$ & $(0.345)$ & $(0.618)$ & $(0.358)$ & $(0.502)$ & $(0.294)$ \\
Log Private Electricity & -0.0412 & 0.0305 & 0.0109 & -0.0178 & -0.00116 & 0.00954 & -0.00808 \\
& $(0.0343)$ & $(0.0672)$ & $(0.0144)$ & $(0.0253)$ & $(0.0145)$ & $(0.0195)$ & $(0.0121)$ \\
Log Private & -0.0773 & -1.658 & 0.376 & $1.761 * * *$ & $1.254 * * *$ & $1.901 * * *$ & $1.867 * * *$ \\
Transportation & $(0.302)$ & $(1.116)$ & $(0.254)$ & $(0.278)$ & $(0.201)$ & $(0.193)$ & $(0.136)$ \\
Constant & -4.135 & 31.52 & -9.087 & $-33.67 * * *$ & $-16.75 * * *$ & $-28.21 * * *$ & $-20.93 * * *$ \\
& $(15.37)$ & $(27.19)$ & $(5.426)$ & $(9.722)$ & $(5.530)$ & $(7.546)$ & $(4.636)$ \\
Observations & 23 & 23 & 23 & 23 & 23 & 23 & 23 \\
R-squared & 0.549 & 0.947 & 0.999 & 0.986 & 0.999 & 0.995 & 0.997 \\
\hline
\end{tabular}




\section{General Equilibrium Policy Simulations}

\section{Egypt}

There are three simulations done which we refer to as: baseline, revolution, and revolution with tax cut. The model is calibrated to the Egyptian economic data for the years 2008, the year of the SAM, to 2010, the year for the national accounts, and using some new data from 2011 and onward regarding tax changes. The baseline model includes no exogenous shocks or alternative policies implemented. The revolution simulation includes a $70 \%$ decrease in the foreign demand for those industries that were hit hardest by the revolution: tourism, transportation, hotels and restaurants, as well as trade and finance. This shock is conducted for a single time period to isolate the effect of the foreign trade aspect of the revolution in that year and on the long term growth path. The final simulation, revolution with tax cut, is identical to the revolution treatment except the corporate income tax is reduced by $25 \%$ for the duration of the model to study the effects of the revolution on the economy with an alternative fiscal policy that encourages higher tax compliance.

\section{Results}

In analyzing these results we look at the macroeconomic effects on the economy and the government's budget, the effects on consumers' utility and income, and the effects on the sectors' participation in the formal economy.

\section{A Gross Domestic Product}

Regarding the growth rate, in Figure 1 we find that our model, absent the revolution, predicts a return to the robust growth rates seen in the 2005-2010 time period when our SAM was built. However, Figures 1 and 2 reveal that with the revolution the real GDP growth rate is 4.3\% less than the baseline in the absence of the lower tax on capital. With the lower corporate 
income tax rate, we see a $3 \%$ net decrease from the higher growth path. The long term effect on GDP of the one year shock is to diminish real GDP by $3.25 \%$ five years after the revolution. The effect on GDP is diminished though a more robust growth path in the presence of a tax cut on corporations.

Figure 1

\section{Real GDP Growth Rates}

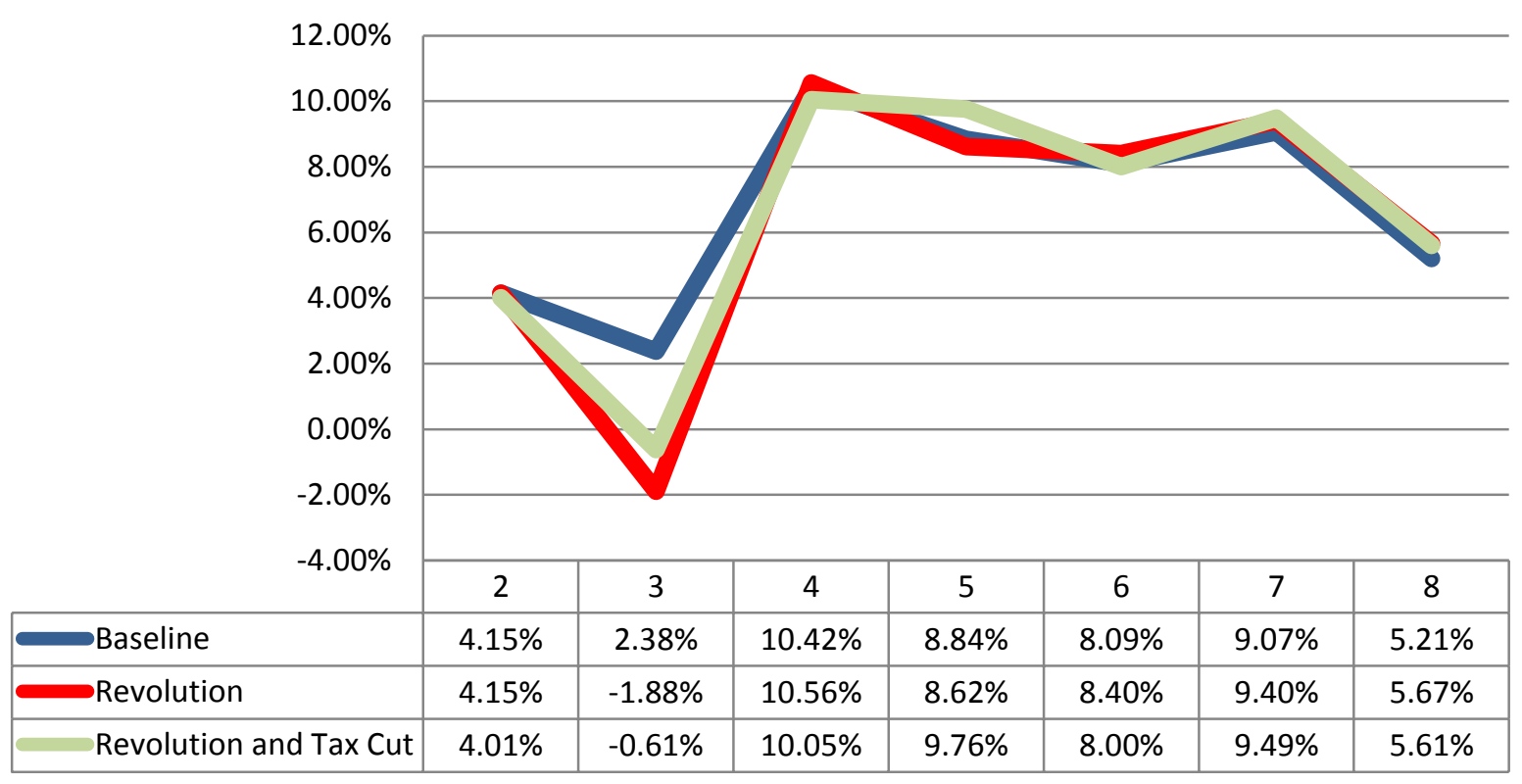




\section{Figure 2}

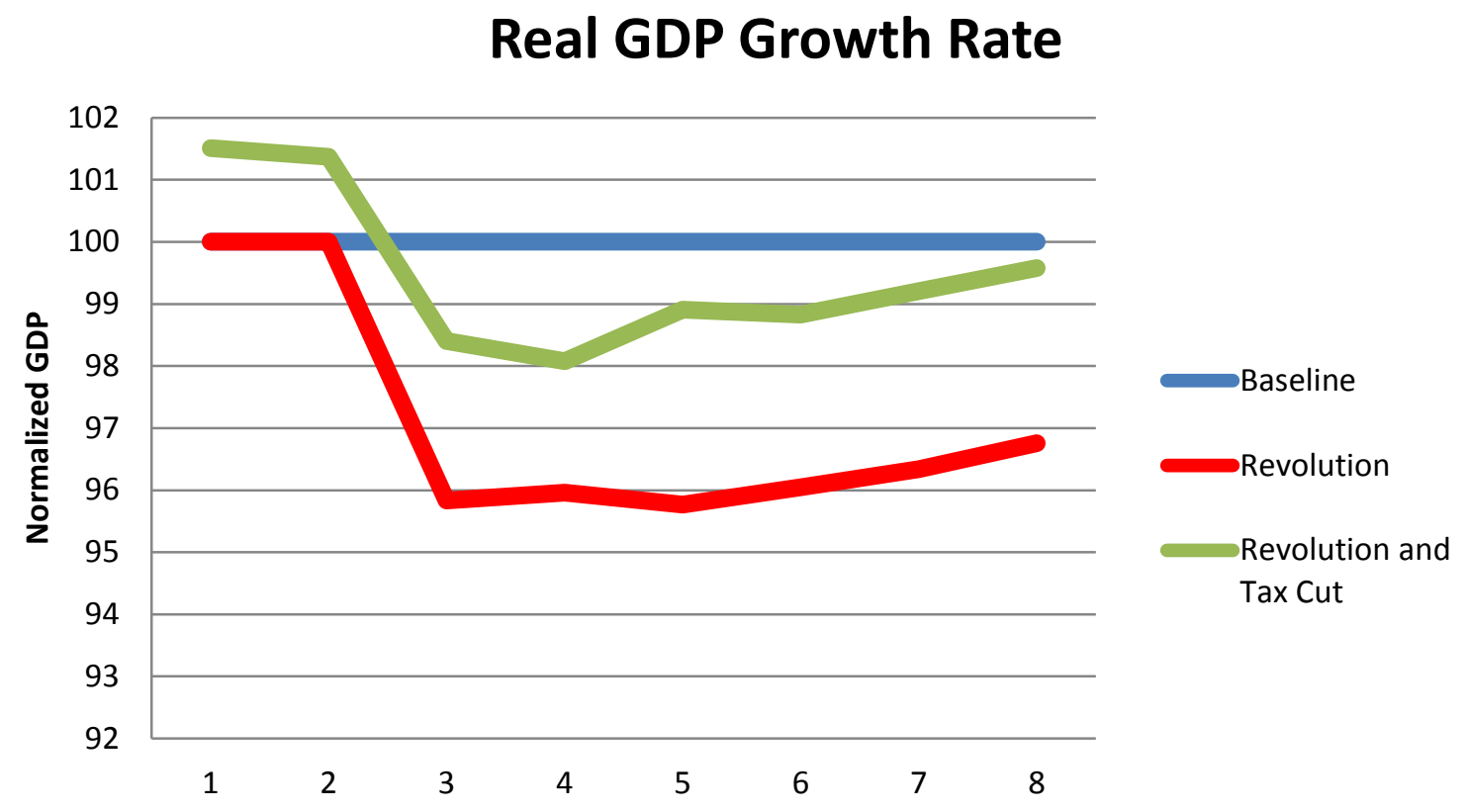

\section{B Inflation}

Regarding inflation, our simulation results again show a return to the high inflation found from 2008-10 during the time our data was extracted, when inflation averaged 13.6\%. Our baseline inflation rate averages $10.9 \%$ in the baseline and ranges from $5 \%$ to $17.4 \%$. Inflation for the revolution simulation is lower over the simulation with an average of $10.6 \%$ while the final treatment including the tax cut has an average inflation rate of $11.5 \%$. Figure 3 reveals the increasing inflation and the effect the effect of the revolution and tax cut on it over the duration of the simulation. 


\section{Figure 3}

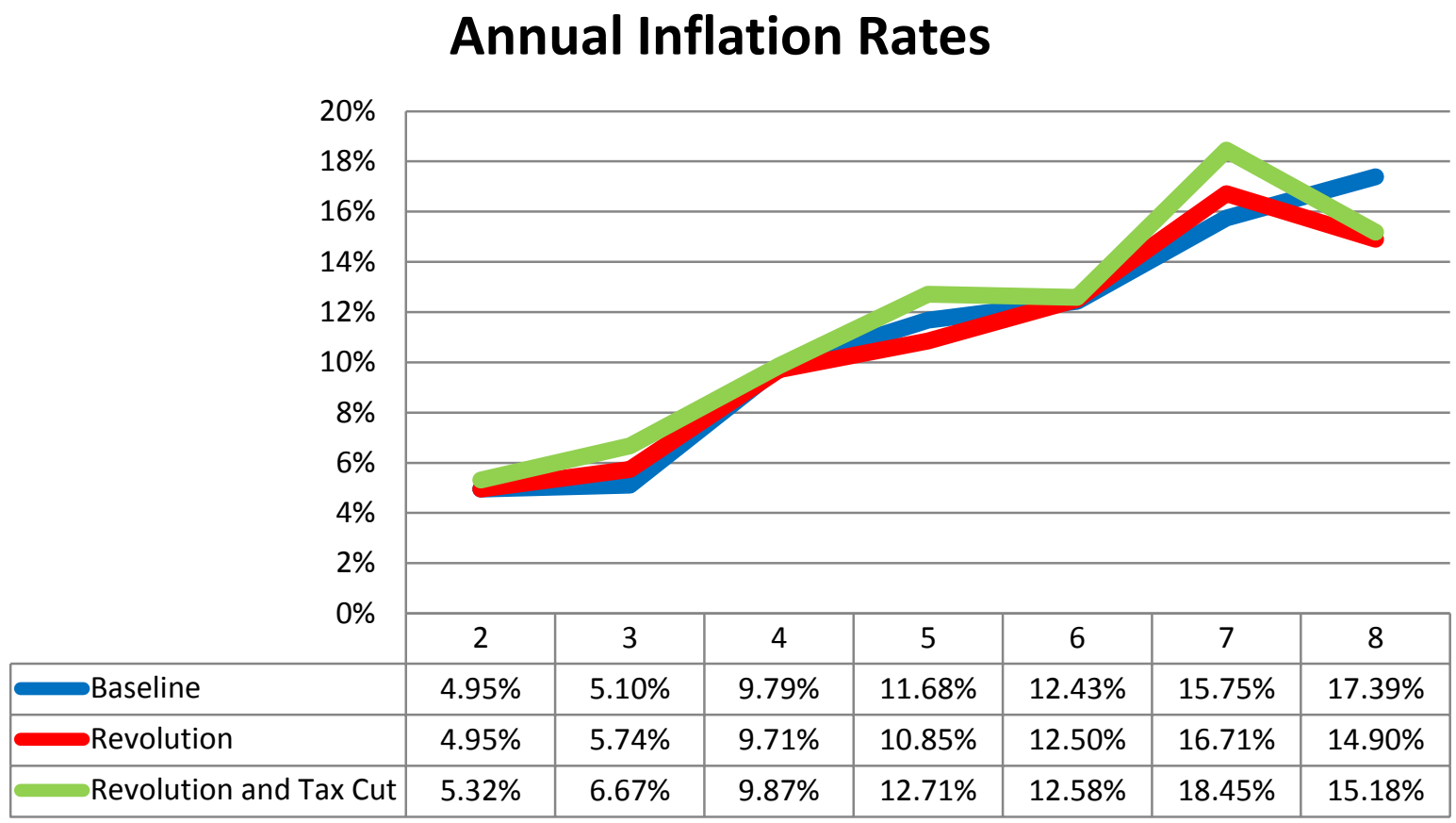

\section{Budget}

Figure 4 shows that the revolution has a negligible effect on the tax collections as a percent of GDP though they are slightly lower as a result of lower tax revenues on those sectors impacted by the revolution, but this effect is offset by the diminished economy in that simulation. As we would expect, the lower tax rate on corporations does diminish tax revenue as a percentage of the overall economy. However, the decrease in revenue is not the absolute amount that a static analysis would reveal, as additional firms enter the formal economy and begin paying taxes on their capital in order to access capital markets. Figure 4 also shows that the model predicts a slight increase in the tax to GDP revenue from approximately $19 \%$ to a bit less than $21 \%$. 


\section{Figure 4}

Tax Revenue to GDP Ratio

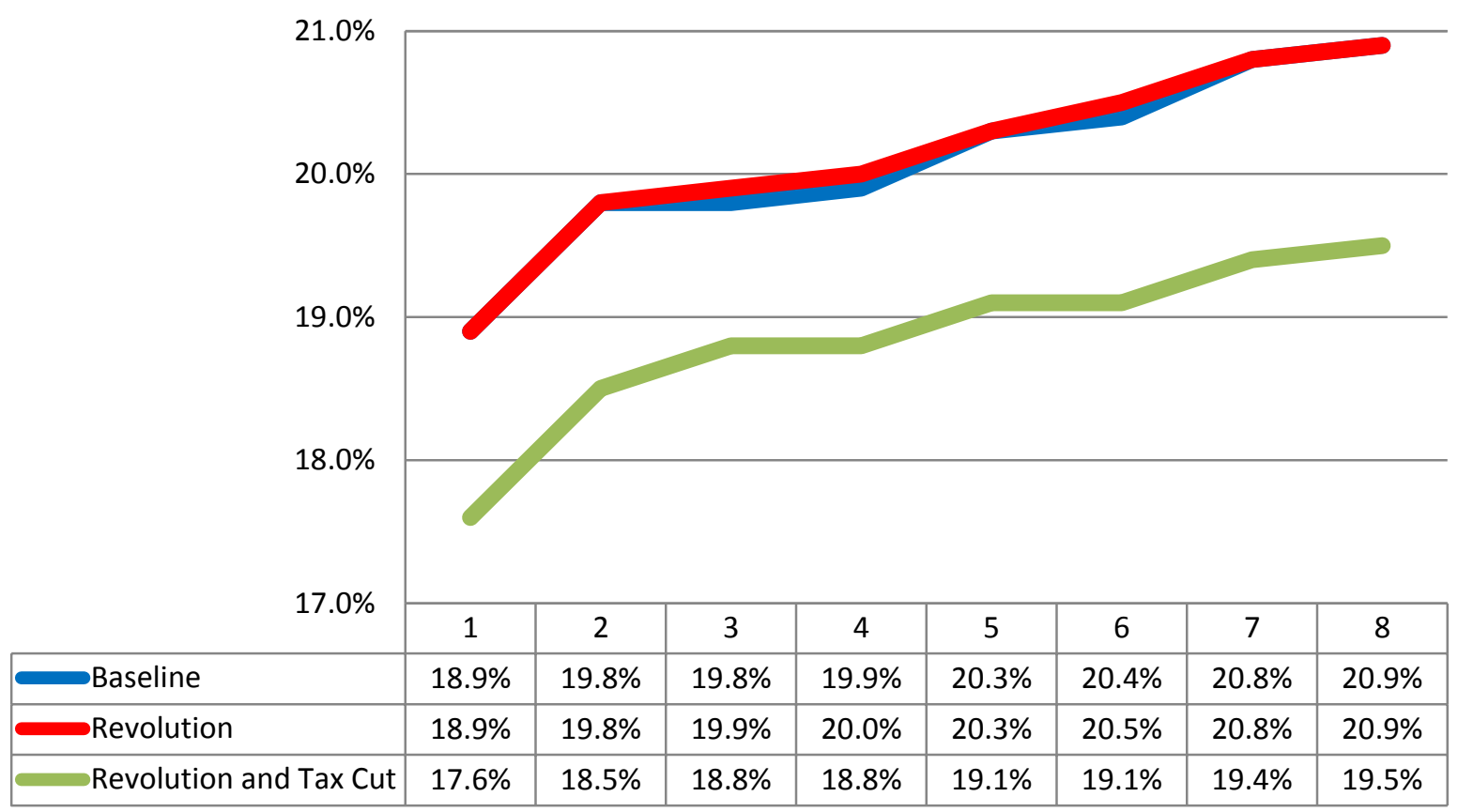

Regarding deficits, we see that the government is running increasingly large deficits into the future. The problem of the deficit is exacerbated by the revolution and further compounded by the tax cut. 


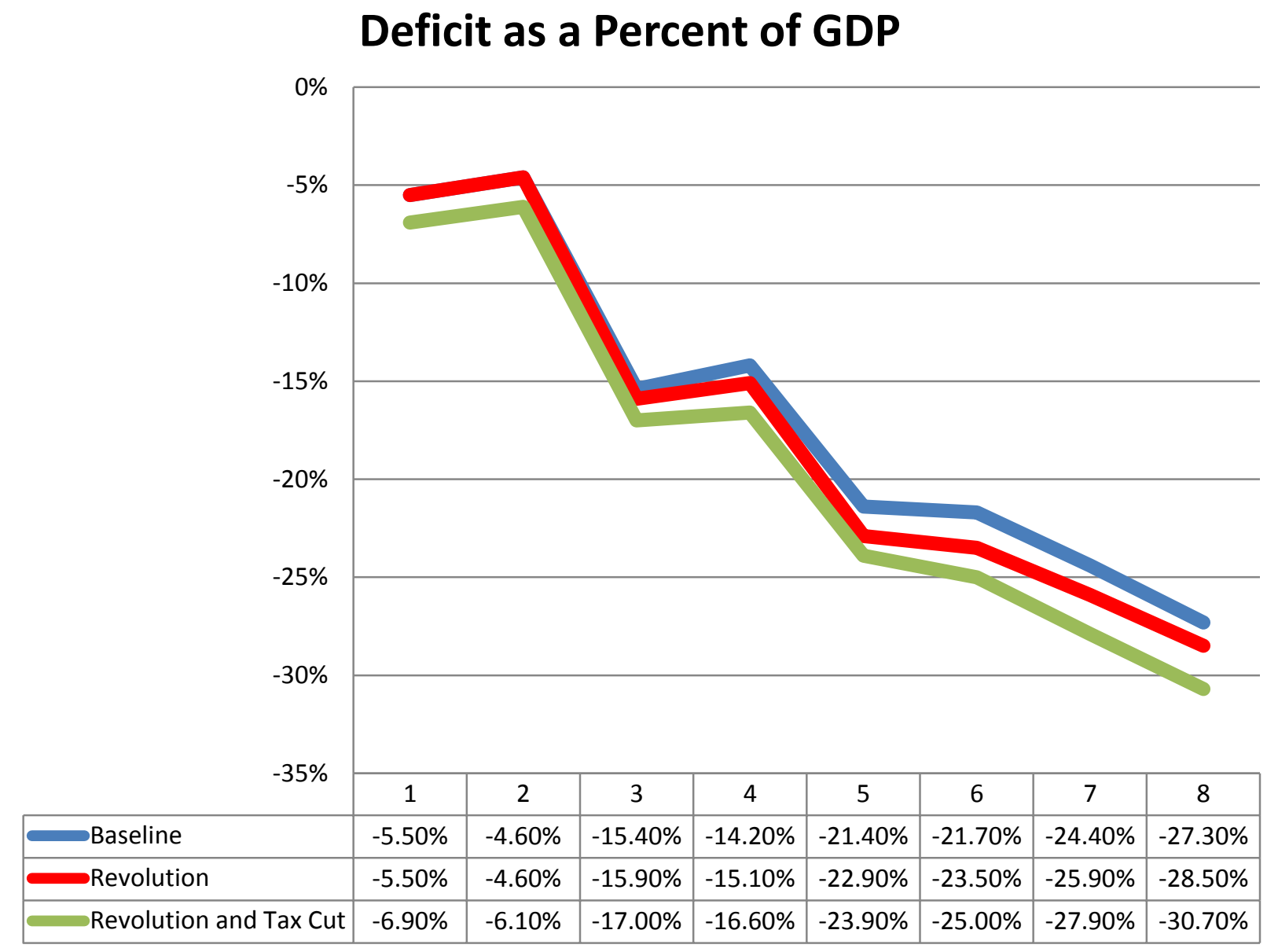

\section{Consumers}

In Table 3 we see the real incomes of the ten consumer groups in period 8. Consumers 15 are urban, consumers 6-10 are rural, and the quintiles are increasing so the poorest quintiles are 1 and 6. The first thing to note is that the urban consumers are considerably wealthier than their rural counterparts. In fact, all but the poorest urban quintile are richer than the richest rural quintile. We also see the effects of the simulated revolution hit the urban consumers especially hard while the rural consumers are slightly helped. This result occurs because the diminished 
foreign demand hits urban labor, provided by urban consumers, almost exclusively. The result of the diminished demand for goods produced using urban labor is a diminished relative urban wage. We also see in the results that the increased growth provided by the lower tax rate on capital brings urban consumers back to the baseline while increasing the gains by rural consumers.

Table -2 : Real income in period 8 by consumer

\begin{tabular}{cccccc} 
& Baseline & \multicolumn{2}{c}{ Revolution } & \multicolumn{2}{c}{ Revolution with Tax Cut } \\
\hline & Income & Income & \% Change & Income & \% Change \\
\hline Urban & & & & & \\
Consumer 1 & 14.6 & 13.8 & $-5.33 \%$ & 14.6 & $-0.02 \%$ \\
Consumer 2 & 21.3 & 20.1 & $-5.36 \%$ & 21.3 & $-0.04 \%$ \\
Consumer 3 & 26.5 & 25.2 & $-5.23 \%$ & 26.6 & $0.09 \%$ \\
Consumer 4 & 35.2 & 33.5 & $-4.92 \%$ & 35.4 & $0.40 \%$ \\
Consumer 5 & 76.6 & 74.3 & $-3.03 \%$ & 78.3 & $2.26 \%$ \\
Rural & & & & & \\
Consumer 6 & 3.5 & 3.9 & $13.34 \%$ & 4.1 & $18.38 \%$ \\
Consumer 7 & 4.9 & 5.5 & $12.30 \%$ & 5.8 & $17.37 \%$ \\
Consumer 8 & 6.1 & 6.8 & $11.96 \%$ & 7.1 & $17.01 \%$ \\
Consumer 9 & 7.6 & 8.5 & $11.63 \%$ & 8.9 & $16.69 \%$ \\
Consumer 10 & 19.6 & 21.3 & $8.36 \%$ & 22.2 & $13.00 \%$ \\
\hline
\end{tabular}

In Table 3 we see the utility values in period 8 relative to the baseline which is normalized to 100. Again, we see in the revolution simulation that the rural consumers gain from the increased relative wage rate and the urban consumers suffer. However, with the inclusion of the tax cuts, the losses for the urban consumers are largely diminished or reversed while the rural consumers have their gains increased. 
Table-3: Utility in period 8 by consumer

\begin{tabular}{cccccc} 
& Baseline & \multicolumn{2}{c}{ Revolution } & \multicolumn{2}{c}{ Revolution with Tax Cut } \\
\hline Consumer & Utility & Utility & $\%$ Change & Utility & $\%$ Change \\
\hline Urban & & & & & \\
Consumer 1 & 100.0 & 88.8 & $-11.2 \%$ & 95.2 & $-4.8 \%$ \\
Consumer 2 & 100.0 & 92.3 & $-7.7 \%$ & 98.5 & $-1.5 \%$ \\
Consumer 3 & 100.0 & 93.8 & $-6.2 \%$ & 99.9 & $-0.1 \%$ \\
Consumer 4 & 100.0 & 95.0 & $-5.0 \%$ & 101.0 & $1.0 \%$ \\
Consumer 5 & 100.0 & 98.9 & $-1.1 \%$ & 104.7 & $4.7 \%$ \\
Rural & & & & & \\
Consumer 6 & 100.0 & 121.2 & $21.2 \%$ & 127.3 & $27.3 \%$ \\
Consumer 7 & 100.0 & 120.8 & $20.8 \%$ & 126.7 & $26.7 \%$ \\
Consumer 8 & 100.0 & 121.6 & $21.6 \%$ & 127.3 & $27.3 \%$ \\
Consumer 9 & 100.0 & 121.9 & $21.9 \%$ & 127.6 & $27.6 \%$ \\
Consumer 10 & 100.0 & 116.3 & $16.3 \%$ & 120.9 & $20.9 \%$ \\
\hline
\end{tabular}

E Formal Sector

Our final variable of interest is the level to which sectors are entering or leaving the formal sector of the economy. Figures 6 and 7 show the percent of each capital sector which is participating in the formal economy relative to the baseline for the two alternative treatments. In Figure 6 we see that Heavy Industry and Electricity, Water, and Sewage decrease their level of compliance and thus operate in the informal sector at a greater rate as a result of the revolution. The other industries are not affected. 
Figure 6

\section{Tax Compliance Relative to the Baseline: Revolution}

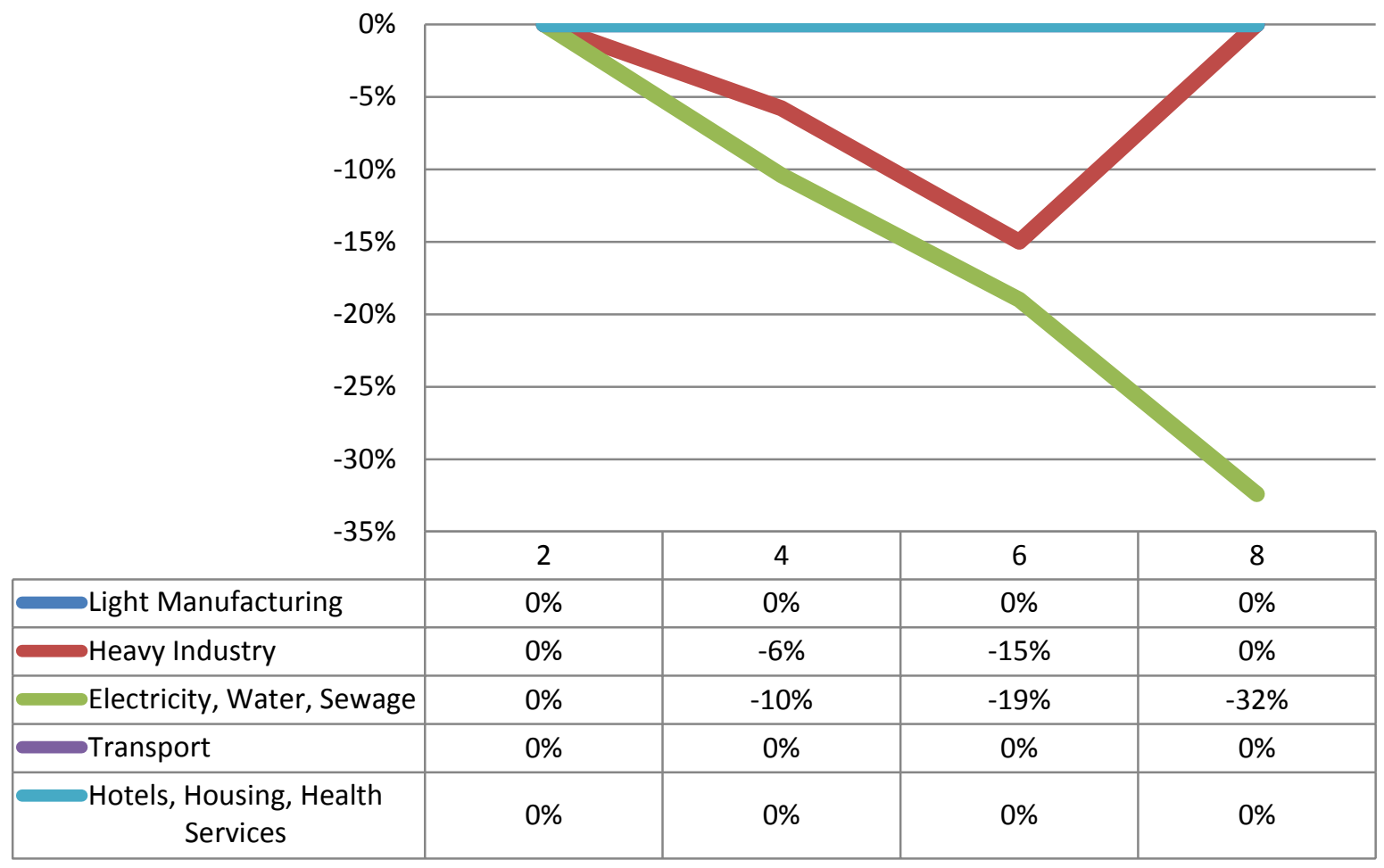

Figure 7 shows the effect on participation in the formal economy of the capital sectors relative to the baseline in the final treatment. Here we see that the decreased tax on capital has an unambiguously positive impact, despite the revolution, on participation in the formal economy as all capital sectors operate in the formal sector at an equal or greater rate. This is as theory would predict, given that the lower tax rate increases the return to capital and thus makes borrowing capital more attractive and thus paying taxes to verify assets more attractive. Also of note is that transportation and light manufacturing are not effected in either simulation. 
Figure 7

\section{Tax Compliance Relative to the Baseline: Revolution with Tax Cut}

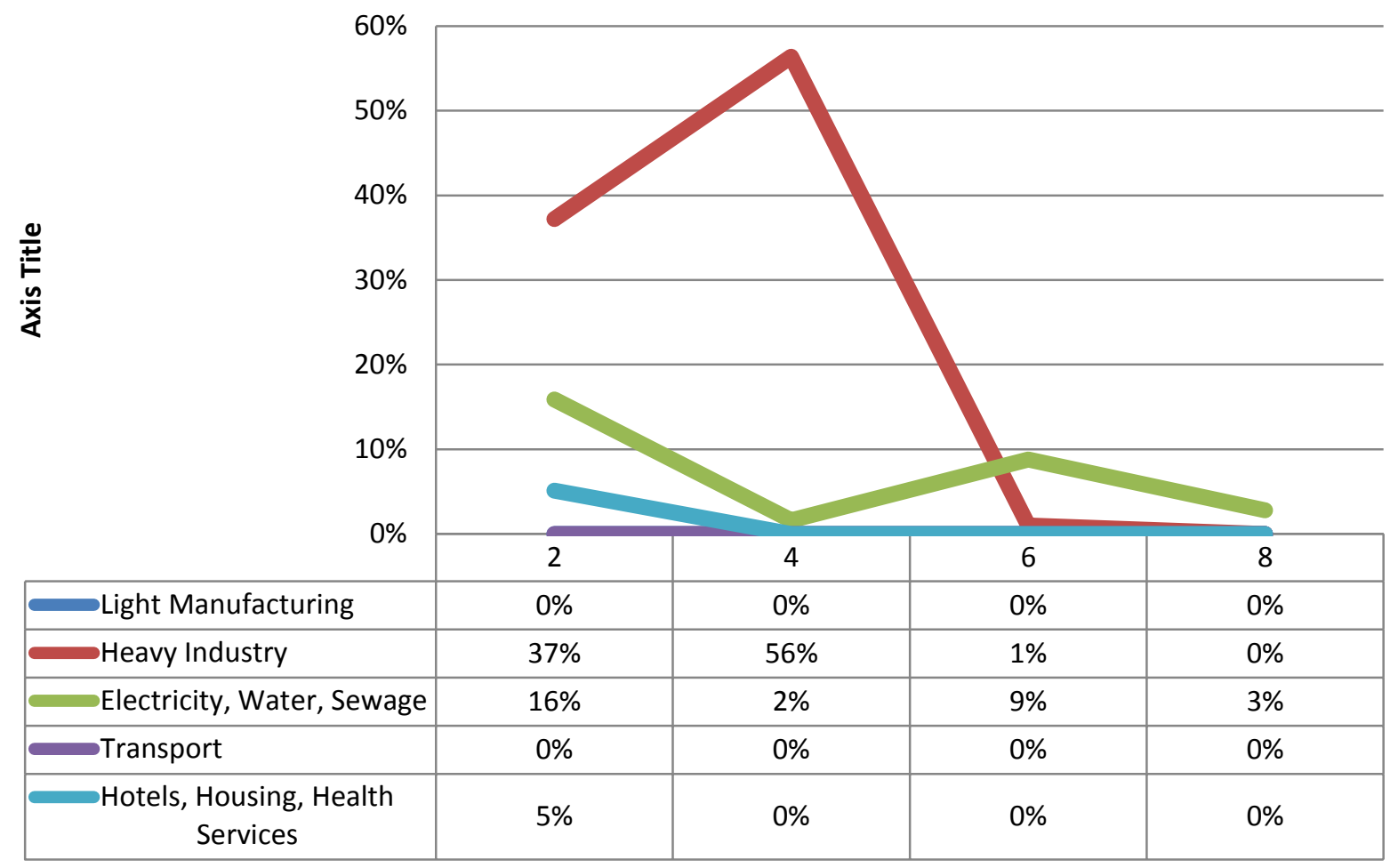

In conclusion, we see that reducing tax evasion by lowering the corporate tax rate has positive benefits for Egypt, although the resulting growth increase will not fully compensate for the loss in tourism.

\section{Mauritius}

In order to analyze growth in Mauritius, we have parameterized the same general equilibrium model as used for Egypt. Our policy focus here is on the role of infrastructure in enhancing growth, rather than on tax policy and tax evasion, as was the case with Egypt. The implementation of our model is based upon several data sources for Mauritius, in particular an 
input-output matrix and a social accounting matrix (SAM), both representing 2007. These and other data sources are given in the bibliography.

After calibrating our model to the 8 year period 2005-2012, we run a series of forward looking simulations for the years 2012-2019. In the first of these, all public policy parameter, such as tax rates, current public expenditure, proportions of the budget deficit financed by debt and monetization, and all transfer payments, are assumed to remain constant. In addition, we will assume the country maintains a fixed exchange rate with the rate fixed at the level of 2012. In particular, we will assume that the level of public capital expenditure is kept at 0 for each of the 8 years of the simulation. This simulation will represent a benchmark, or base case, to be used for comparisons with alternative scenarios about public capital spending. It should not be viewed as having any predictive indications for the future. The results of this benchmark simulation are given in Table $1 \mathrm{M}$.

TABLE 1M: BASE CASE YEAR

$\begin{array}{lrrrrrrrr}\text { (based on 2012) } & 1 & 2 & 3 & 4 & 5 & 6 & 7 & 8 \\ \text { REAL GDP 1/ } & 100.0 & 108.1 & 111.7 & 115.8 & 124.0 & 125.9 & 130.6 & 131.5 \\ \text { NOMINAL GDP 1/ } & 100.0 & 133.8 & 188.2 & 245.6 & 350.8 & 452.1 & 598.0 & 764.4 \\ \text { PRICE LEVEL 1/ } & 100.0 & 123.7 & 168.6 & 212.1 & 283.0 & 359.0 & 458.0 & 581.4 \\ \text { TAX REVENUES 2/ } & 17.3 & 18.6 & 19.6 & 19.8 & 19.8 & 20.1 & 20.2 & 20.4 \\ \text { GOV. EXPENDITURES 2/ } & 24.4 & 27.2 & 35.0 & 35.7 & 35.0 & 35.9 & 37.1 & 37.8 \\ \text { GOV. DEFICIT 2/ } & -7.1 & -8.7 & -15.5 & -15.9 & -15.2 & -15.9 & -16.9 & -17.5 \\ \text { INTEREST RATE } & 27.3 & 16.3 & 11.2 & 10.3 & 8.6 & 9.1 & 7.0 & 7.2 \\ \text { EXPORTS 2/ } & 35.3 & 21.4 & 26.7 & 24.5 & 21.6 & 20.0 & 19.2 & 17.9 \\ \text { IMPORTS 2/ } & 34.1 & 34.8 & 31.7 & 30.5 & 27.6 & 27.0 & 25.7 & 25.4 \\ \text { TRADE DEFICIT 2/ } & 1.2 & -13.4 & -5.0 & -6.0 & -6.0 & -7.0 & -6.5 & -7.5\end{array}$

$1 /$ Index numbers based upon year 1

2/ As percent of GDP

We notice that average annual real growth is about 4.0 percent, which is approximately the rate for the period prior to 2012, the base year of our simulation. Tax revenues are 
essentially constant as a share of GDP, while expenditures grow as the interest obligations on the debt burden grow. We should note that tax revenues here do not include other sources of revenues, so that our measure of the budget deficit is larger than historical measures. The interest rate eventually stabilizes at about 7.0 percent, and the trade deficit slowly deteriorates in response to the fixed exchange rate. Similarly, real GDP growth stagnates by the final periods, partly in response to the fixed exchange rate, but also because of the lack of growth in public infrastructure.

Suppose we now ask to what extent can the real growth rate be increased if the government increases infrastructure spending, which was assumed to be 0 in the previous example. The mechanism for such an increase in growth would be through the estimated elasticities of private output with respect to public infrastructure, given in Table 4. In order to avoid combining the increase in growth generated by increased private sector productivity with the growth generated by a Keynesian spending increase, we will assume that the public infrastructure spending increase is compensated for by a corresponding decrease in current expenditure. Of course such current spending cuts might not be politically possible, so we should view this as a mechanical exercise designed to isolate the effects of private sector efficiency increases from the impact of general public spending increases. At the same time, we might expect that increases in public infrastructure would raise the return to private investment, thereby increasing the rate of capital formation in the short run. In the long run, capital deepening and the corresponding decrease in the return to capital may cause investment and GDP growth to slow.

As a first example, we will increase public spending on infrastructure to 10 percent of GDP, with a corresponding cut in current expenditure. We will further assume that the spending 
increase is allocated uniformly across the different categories of infrastructure. ${ }^{9}$ This example would thus be the least inflationary scenario for the country, since there would be no increase in deficit spending caused by the increased infrastructure. We will also be able to differentiate between the growth effects of the infrastructure and Keynesian spending effects. The results of this exercise are given in Table $2 \mathrm{M}$.

TABLE 2M: CAPITAL EXPEND. YEAR

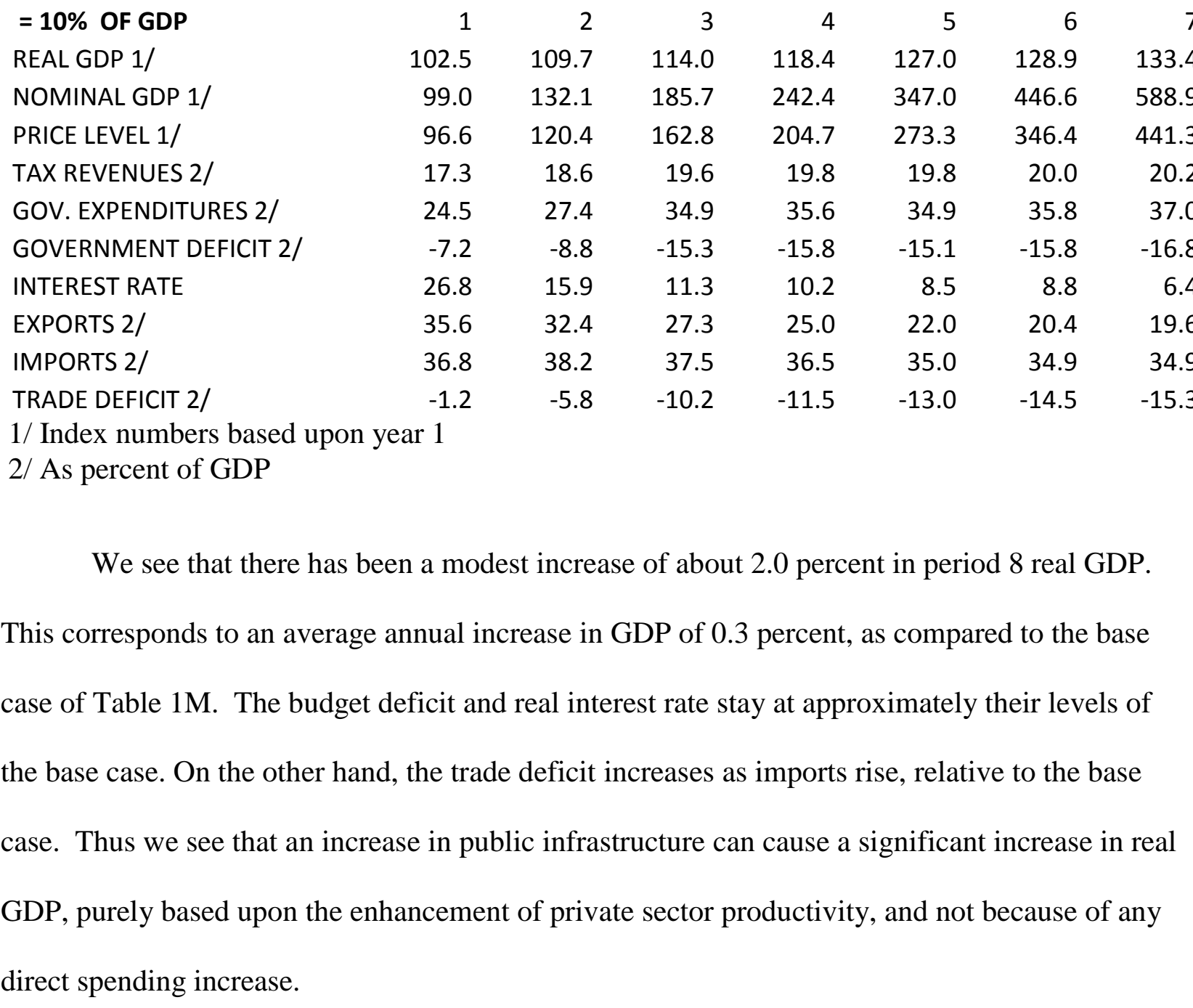

\footnotetext{
${ }^{9}$ An alternative would be to have infrastructure allocated according to the relative elasticities of public infrastructure with respect to different sectors of the economy, depending upon which sectors the government wishes to promote.
} 
We now may wish to ask how far we can increase infrastructure spending and continue to achieve real GDP growth. If, for example, an increase in infrastructure spending from 0 percent of GDP to 10 percent of GDP, as above, leads to a rise in real GDP, how would increases to 15 or 20 percent of GDP be? Rather than giving the complete macro outcomes once again, Table 3M below summarizes the real GDP outcomes of 4 alternative simulations. These are the base case of 0 public infrastructure spending, then 10,15 and 20 percent of GDP spending on public infrastructure, each with a corresponding reduction in current spending.

\section{Table 3M: REAL GDP}

PERIOD

Infrastructure spending $1 /$

0

10

15

20

1/ Percent of GDP

\section{1}

100.0

102.5

103.2

103.8
2

108.1

109.7

110.7

112.4

3

111.7

114.0

115.3

116.4
3

4

115.8

118.4

119.8

121.1
(1)

5

124.0

127.0

128.3

129.8

$\begin{array}{rrr}6 & 7 & 8 \\ 125.9 & 130.6 & 131.5 \\ 128.9 & 133.4 & 134.1 \\ 130.5 & 135.2 & 136.9 \\ 132.2 & 136.7 & 136.5\end{array}$

We see that real GDP increases as infrastructure spending increases from 0 to 15 percent of GDP. However a further increase in spending to 20 percent of GDP actually leads to a decline in real GDP by period 8, even though real GDP remains above the levels achieved with 15 percent spending for the first 7 time periods. We see the importance of using a dynamic model with many time periods, since looking at only the first few periods would lead us to conclude that increasing spending on infrastructure from 15 to 20 percent of GDP will lead to an overall increase in real GDP. In fact, further increases in infrastructure spending beyond 20 percent of GDP lead to further declines in real GDP growth.

Thus we may conclude that, in the case of Mauritius, modest increases in spending upon infrastructure may lead to corresponding increases in real GDP. Our analysis is subject to a 
number of caveats. We suppose that increases in infrastructure spending are compensated for by corresponding decreases in current spending. Also, we have not considered alternative ways of distributing spending across the different types of public infrastructure, but have simply assumed that spending is uniformly distributed, which may be sub-optimal. Finally, our results are sensitive to the estimated elasticities of Table 4, leading us to inject a word of caution in interpreting the results.

\section{Conclusion}

We have constructed a dynamic multi-period general equilibrium model and have used it to analyze prospects for growth in two very different countries, Egypt and Mauritius. The use of a single model has the advantage that when comparing alternative policies across countries, it is not necessary to worry if different conclusions are based solely upon model differences, as would be the case with multiple models.

In the case of Egypt we have looked at a the effects of the revolution of 2011 on growth, in particular, at the impact of a dramatic decline in tourism. In addressing the issue of how to increase growth we focused upon a particular problem in Egypt, namely the low rate of tax compliance. Accordingly, we looked at fiscal policies designed to reduce tax evasion, and have found that these policies are also successful in modestly increasing GDP growth.

Mauritius has not suffered from any immediate shock, as has Egypt. However shortages in public infrastructure have been identified as bottlenecks in GDP growth, which, it should be noted, has slowed in recent years. We have therefore estimated elasticities of private production with respect to stocks of public infrastructure, and have used these elasticities to implement our general equilibrium model. We find that modest increases in spending upon public 
infrastructure, compensated for by corresponding decreases in current spending, can lead to increases in real GDP growth. Beyond certain levels, however, more infrastructure spending will actually lead to a decline in real GDP growth. 


\section{References}

Berndt, E. R., \& Wood, D. O. (1975). Technology, Prices, and the Derived Demand for Energy. The Review of Economics and Statistics , 57 (3), 259-268.

Blejer, M. I., E. V. Feldman, A. Feltenstein (2002). "Exogenous shocks, contagion, and bank soundness: a macroeconomic framework." Journal of International Money and Finance 21(1): 33-52.

Christensen, L. R., Jorgenson, D. W., \& Lau, L. J. (1973). Transcendental Logarithmic Production Frontiers. The Review of Economics \& Statistics , 55 (1), 28-45.

Dabla-Norris, E. R. A. and A. Feltenstein (2005). "The underground economy and its macroeconomic consequences." The Journal of Policy Reform 8(2): 153-174.

De Soto, H. (2011). "Egypt's economic apartheid." Wall Street Journal 3.

Dobronogov, A. and F. Iqbal (2005). Economic growth in Egypt: Constraints and determinants, World Bank Washington.

Exchange rates: Mauritius (2014): http://www.X-rates.com/table/?from=MUR\&amount=1.00

Feltenstein, A., \& Ha, J. (1995). The Role of Infrastructure in Mexican Economic Reform. The World Bank Economic Review , 287-304.

Feltenstein, A., and M. Cyan (2013), "A Computational General Equilibrium Approach to Sectoral Analysis for Tax Potential: An Application to Pakistan," Journal of Asian Economics 27 , pp. 57-80.

Feltenstein, A. and A. Shah (1995). "General equilibrium effects of investment incentives in Mexico." Journal of Development Economics 46(2): 253-269.

Feltenstein, A., and M. Shamloo (2013), "Tax Reform, the Informal Economy, and Bank Financing of Capital Formation", International Tax and Public Finance, Vol. 20, no. 1: pp. 1-28.

Gordon, R. and W. Li (2009). "Tax structures in developing countries: Many puzzles and a possible explanation." Journal of Public Economics 93(7): 855-866.

Harberger, A. (1978). Perspective on Capital and Technology in Less-Developed Countries. In M. J. Artis, \& A. R. Nobay, Contemporary Economic Analysis. London: Croom Helm Ltd.

IMF (2010). Arab Republic of Egypt: 2010 Article IV Consultation - Staff Report. I. M. Fund. 10/94.

IMF. (1996). Mauritius - Background Papers and Statistical Annex. International Monetary Fund. 
IMF (2014), Mauritius 2014 Article IV Consultation-Staff Report. International Monetary Fund. Input-output Matrix for Mauritius, (2007). Republic of Mauritus National Accounts. http://www.gov.mu/portal/site/cso/?content_id=67053bcb6ee6c010VgnVCM1000000a04a8c0R CRD\#hs

Jankee, K. (1999). Financial Liberalisation and Monetary Control Reform in Mauritius. Social Sciences \& Humanities and Law \& Management Research Journal , 2, 10-28.

Social Accounting Matrix for Mauritius (2010) http://statsmauritius.gov.mu/English/StatsbySubj/Pages/Investment.aspx

Taxes: Doing Business in Mauritius (World Bank). 2014

http://www.doingbusiness.org/data/exploreeconomies/mauritius/ /media/giawb/doing\%20busine ss/documents/profiles/country/MUS.pdf?ver=2

Vikram, N., \& Dhareshwar, A. (1993). A New Database on Physical Capital Stock: Sources, Methodology and Results. Revista de Analisis Economica , 8 (1), 37-59. 


\section{Appendix 1}

Mauritius: Time Trend of Sectoral GDP
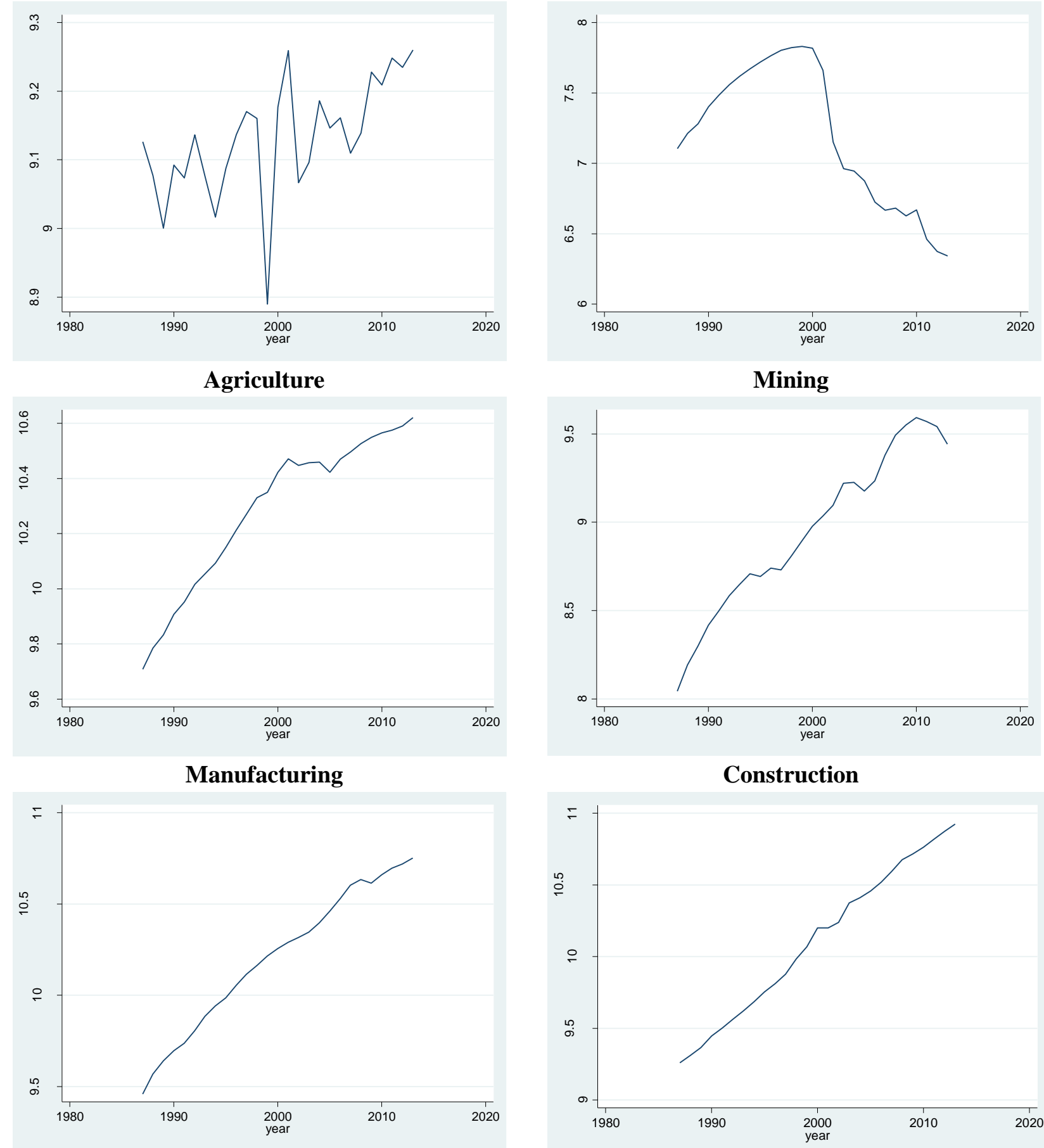

Wholesale

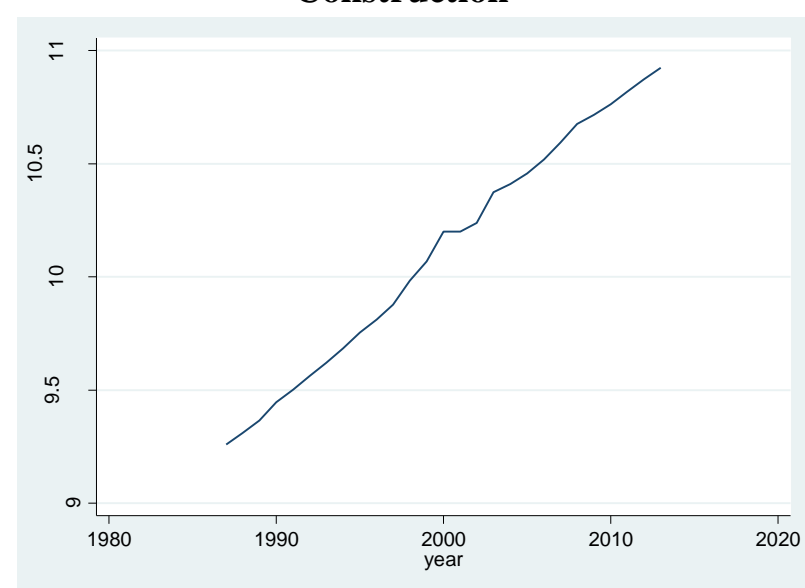

Finance 


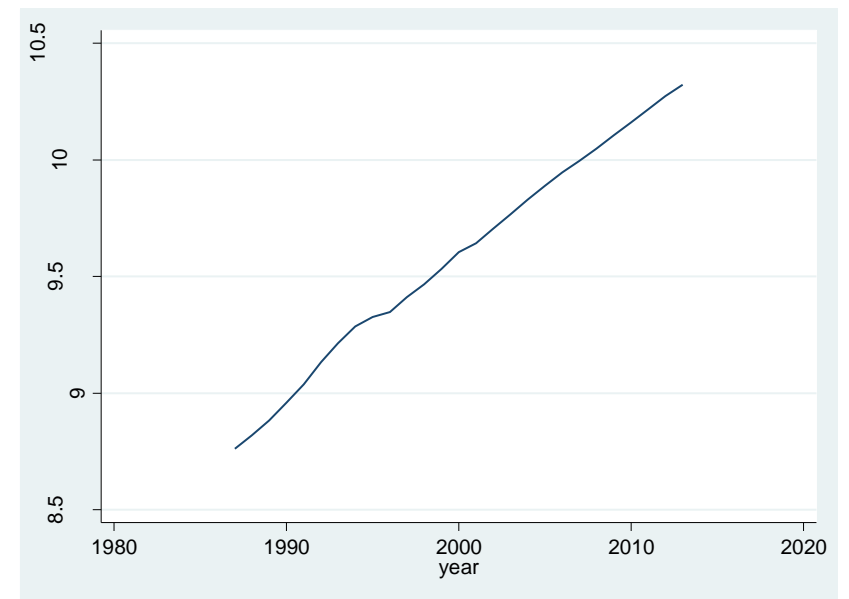

Other

Mauritius: Time Trend of Infrastructure Stock

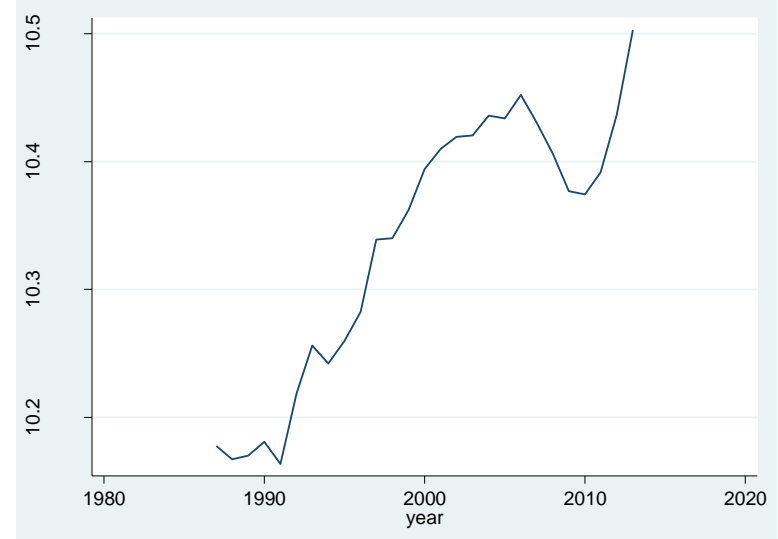

Public electricity

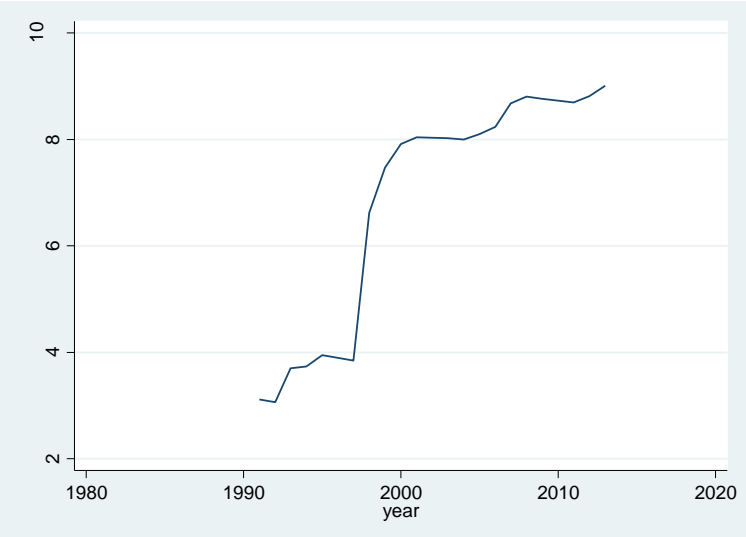

Private electricity

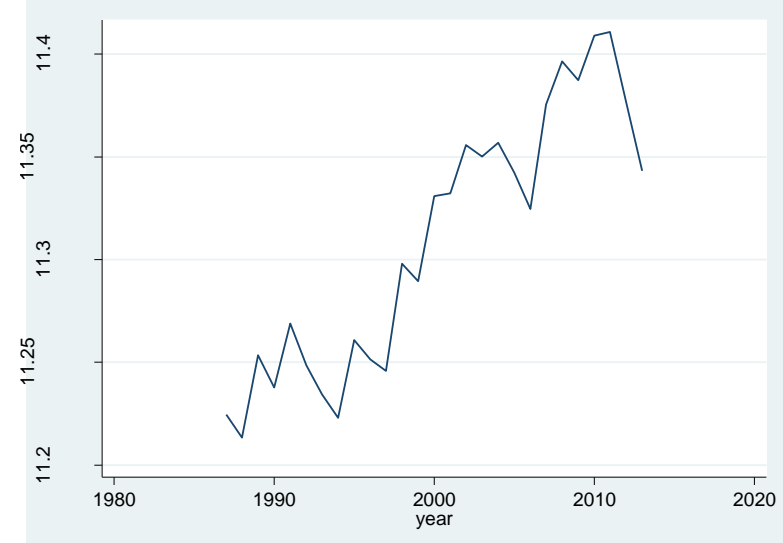

Public transportation

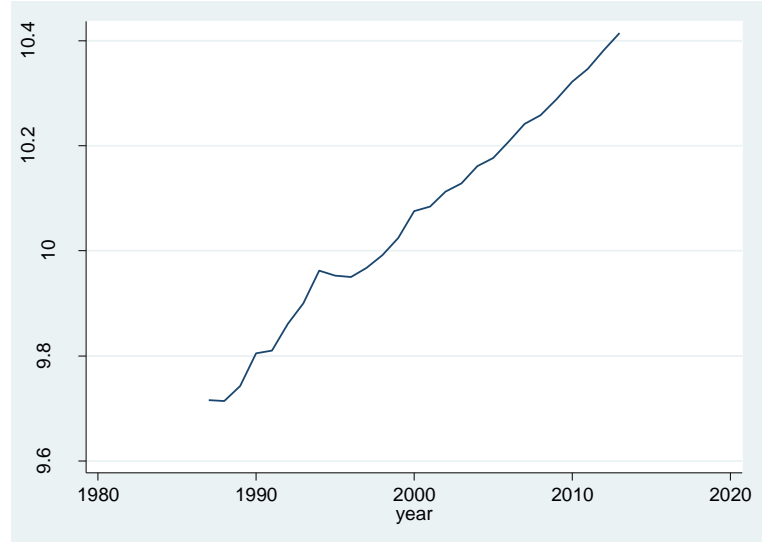

Private transportation 
Time Trend of Sectoral Wages \& Interest Rate

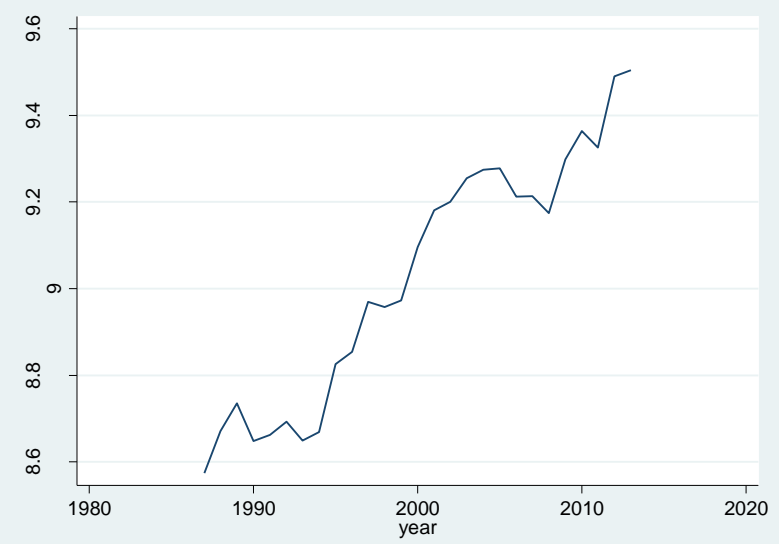

Agriculture

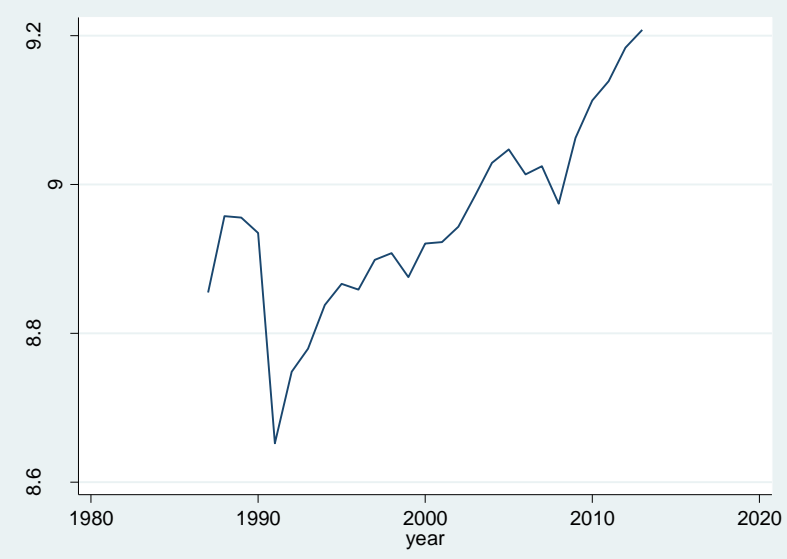

Manufacturing

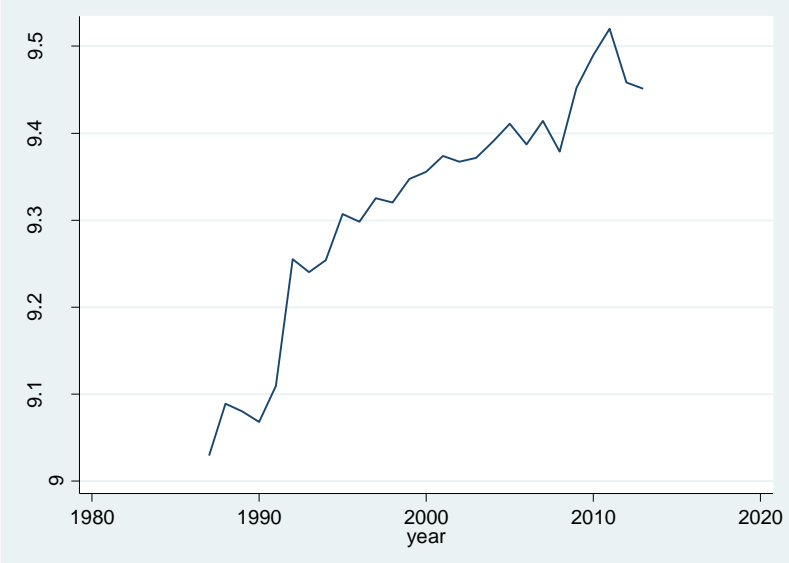

Wholesale

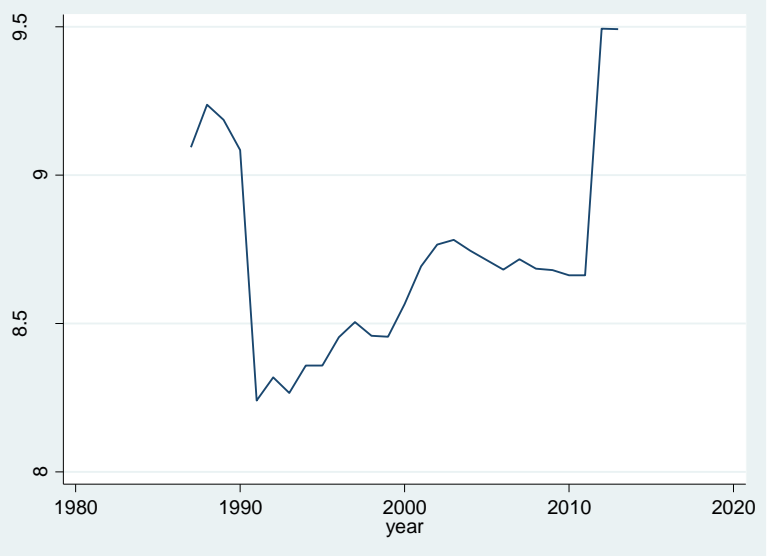

Mining

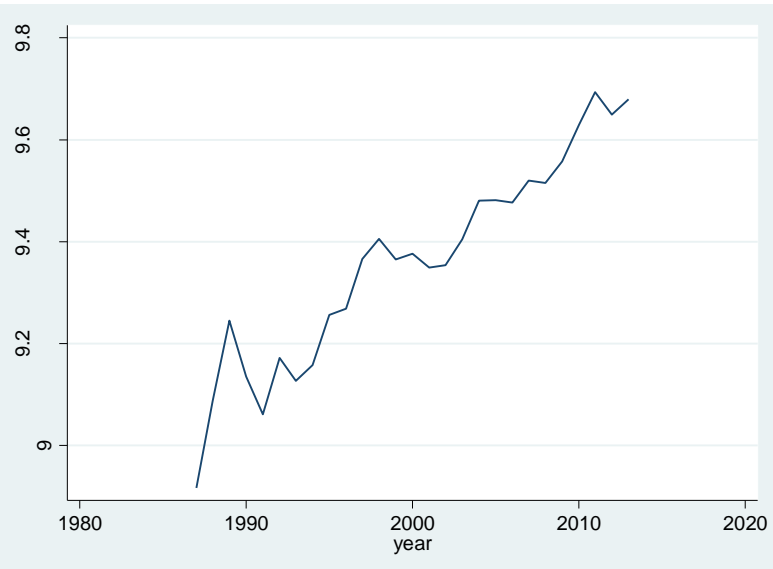

Construction

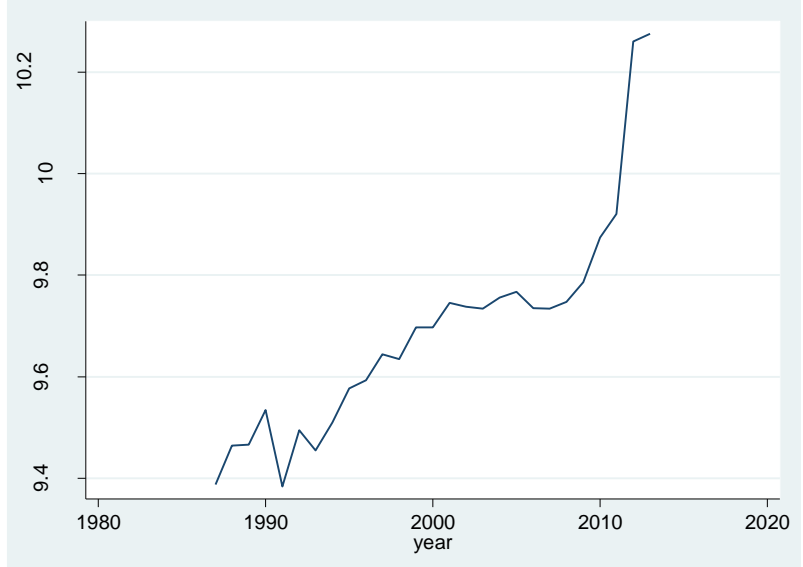

Finance 


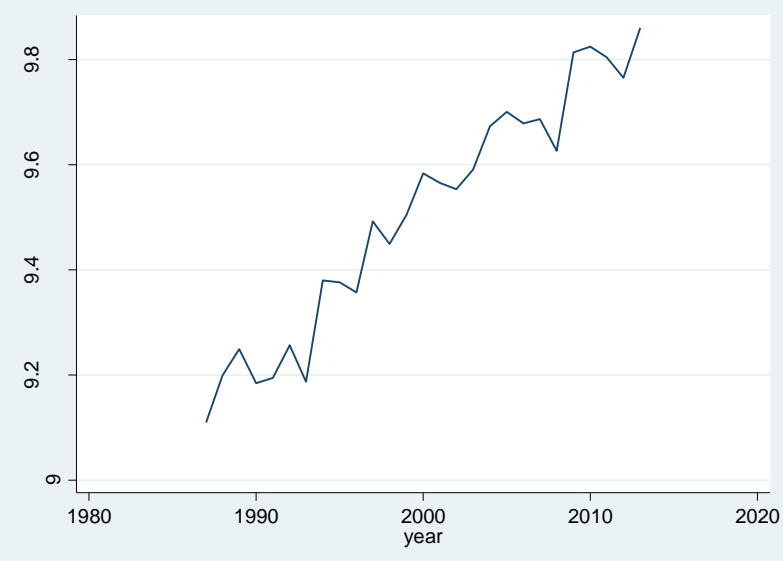

Other

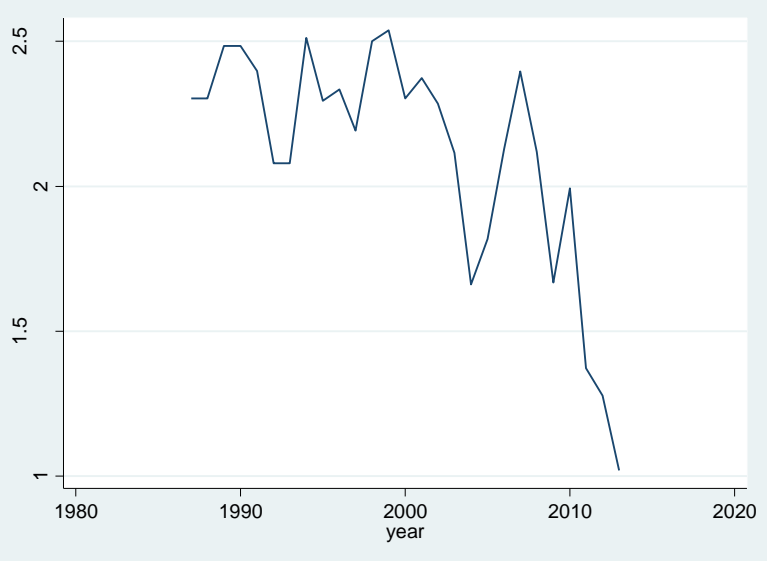

Interest 